\title{
Recovery of Some Critical Raw Materials from Processing Waste of Feldspar Ore Related to Hydrothermally Altered Granite: Laboratory-Scale Beneficiation
}

\author{
Tomáš Vrbický * and Richard Přikryl (D) \\ Institute of Geochemistry, Mineralogy and Mineral Resources, Faculty of Science, Charles University, \\ Albertov 6, 12843 Prague 2, Czech Republic; richard.prikryl@natur.cuni.cz \\ * Correspondence: vrbicky.t@gmail.com; Tel.: +420-721-530-275
}

Citation: Vrbický, T.; Přikryl, R. Recovery of Some Critical Raw

Materials from Processing Waste of Feldspar Ore Related to Hydrothermally Altered Granite: Laboratory-Scale Beneficiation. Minerals 2021, 11, 455. https:// doi.org/10.3390/min11050455

Academic Editor: Nikolaos Kantiranis

Received: 11 March 2021

Accepted: 24 April 2021

Published: 26 April 2021

Publisher's Note: MDPI stays neutral with regard to jurisdictional claims in published maps and institutional affiliations.

Copyright: (c) 2021 by the authors. Licensee MDPI, Basel, Switzerland. This article is an open access article distributed under the terms and conditions of the Creative Commons Attribution (CC BY) license (https:// creativecommons.org/licenses/by/ $4.0 /)$.

\begin{abstract}
Feldspar for ceramic/glass industries requires sufficiently low content of harmful colourants (Fe-, Ti-, Mn-bearing mineral phases). Hydrothermally altered albite-rich granites are increasingly used as feldspar raw material nowadays; however, they are often marked by increased content of colourants, which must be removed during the processing of feldspar ore. Parallel to the content of colourants, these phases show enrichment in some critical raw materials (CRMs), specifically of $\mathrm{Nb}$, $\mathrm{Ta}$, and Li. In the current study, the laboratory trials focused on the possibility of reprocessing of waste generated during basic magnetic separation of feldspar ore. Major aim of these trials was to search for a processing scheme that would allow for obtaining of mineralogically homogeneous fractions, part of which could be utilised as a source of CRMs. According to the results, combination of gravity, magnetic and heavy liquid separation is highly effective in obtaining of desirable concentrates. Feldspar ore processing waste thus presents potential source of CRMs; however, semi-industrial and full-scale trial must follow in order to prove the economic and environmental suitability of the suggested processing scheme.
\end{abstract}

Keywords: feldspar; processing; rutile; Li-micas; niobium-tantalum oxides

\section{Introduction}

Feldspars make one of the basic ingredients of ceramic batches used for manufacturing of floor- and wall-tiles, sanitary ware, table ware, and/or glazes [1,2], which are, at least partly, used in construction industry. Alkalis from feldspars act as a flux during firing of ceramics by allowing for optimum melt formation, for densification and sintering (vitrification), and/or for translucency of the fired ceramic body [3-5]. In ceramic batch formulation, they can be present from several units of wt. $\%$ up to $65 \mathrm{wt} . \%$, depending on the type of the product [6].

Despite their widespread presence in upper-crustal rocks, only some sources of feldspars fulfil strict criteria set by ceramic industry, both in terms of content of alkalis (desirable as high as possible) and of harmful impurities-specifically of colourants such as Fe-, Mn-, and/or Ti-bearing mineral phases [7]. For many of the operated feldspar deposits, separation of feldspars from accompanying mineral phases (phyllosilicates such as micas or clay minerals) and removal of colourants make part of raw material processing flow-chart, mostly using flotation [8-12]. A long-term practice of three-stage flotation in acid medium has been found highly efficient [13]; however, its potential environmental impact leads for the search of alternative methods that can utilise, e.g., contrast physical properties of the individual phases present in the raw material [7]. From these methods, magnetic separation appeared as one of the most effective, specifically in removal of Fe-bearing phases [14]. Quite often, chemical treatment-flotation-and physical beneficiation by magnetic separation are combined [15-18]. Some other perspective beneficiation methods such as bioleaching of Fe-rich phases are searched for as well [19]. 
Due to the abundance of feldspars in upper crustal rocks, feldspar-based ceramic fluxes can be found in a broad range of lithologies and/or tectonic settings [2]. During recent decades, alkali feldspars-rich granites (leucogranites) and their hydrothermally altered derivatives (commonly designated as albitites) are becoming more and more important in modern ceramic industry [2]. In terms of petrogenesis, leucogranites belong to highly evolved granites found in post-orogenic and/or anorogenic granitic provinces around the world $[20,21]$. They are often topaz-bearing, enriched in incompatible elements such as LILE (large-ion lithophile elements) and rare metals such as $\mathrm{Sn}, \mathrm{W}, \mathrm{Mo}, \mathrm{Li}$, and $\mathrm{Nb} / \mathrm{Ta}$ [22]. As consequence of this composition and of specific post-solidification processes including hydrothermally altered zones and/or rock bodies, a range of search-for mineralization evolved in these terranes, e.g., $\mathrm{Sn}-\mathrm{W}(\mathrm{Mo})$ mineralization bound to greisens, various types of pegmatites, REE deposits, etc. [23,24].

In the past decades, numerous studies (reviewed e.g., in [7]) focused on how the feldspar raw material processing can increase quality of the ceramic flux, specifically in terms of removal of harmful components. Surprisingly, none of these studies attempted to explore whether the processing of extracted feldspar raw material can lead not only to the improved quality of the feldspar-based ceramic flux but also to the potential obtaining of valuable raw materials from the feldspar ore processing waste (FOPW). In order to fill this gap in the knowledge, our study brings first data based on detailed laboratory trials of targeted reprocessing of FOPW from the largest operated feldspar deposit in the Czech Republic [25]. Due to the petrogenetic character of the raw material and due to complex mineralogy of minor/harmful phases in it-i.e., hydrothermally/metasomatically altered granite- the experiments were mainly focused on finding the most effective methods that can be used for successful separation of individual phases. The aim of this study is to show that the quality of the raw material can be highly improved not only by careful selection of processing flow-chart but also by the potential of accompanying phases, some of them belonging to the category of "critical raw materials" (CRMs) [26,27]. This study focuses specifically on laboratory trials that are necessary for the successive investigation on semi-industrial and full-scale industrial trials of which publication is under preparation.

\section{Materials and Methods}

\subsection{Locality and Basic Characteristics of Experimental Material}

The experimental material was sampled from the operated Krásno deposit (KrásnoHorní Slavkov ore district), situated in the Saxothuringian zone (western part of the Bohemian Massif, western Bohemia, Czech Republic). The deposit is located in the southern part of the Karlovy Vary Pluton (part of the Krušné hory/Erzgebirge Mts. Batholith, which is a member of Saxo-Danubian Granite Belt megastructure [28]), being associated with the so-called Krudum body [29] within the Slavkovský les crystalline unit (Figure 1). Extensive post-solidification hydrothermal/metasomatic activities in the whole area resulted in the formation of numerous bodies ("stocks") of greisens and/or of albite-rich leucogranites with typical mineral associations and mineralization [30-34]. Feldspar raw material is exploited from Vysoký kámen stock, occupying semioval area of about $400 \mathrm{~m} \times 600 \mathrm{~m}$ with depth down to $190 \mathrm{~m}$ below the surface (Figure 2). 


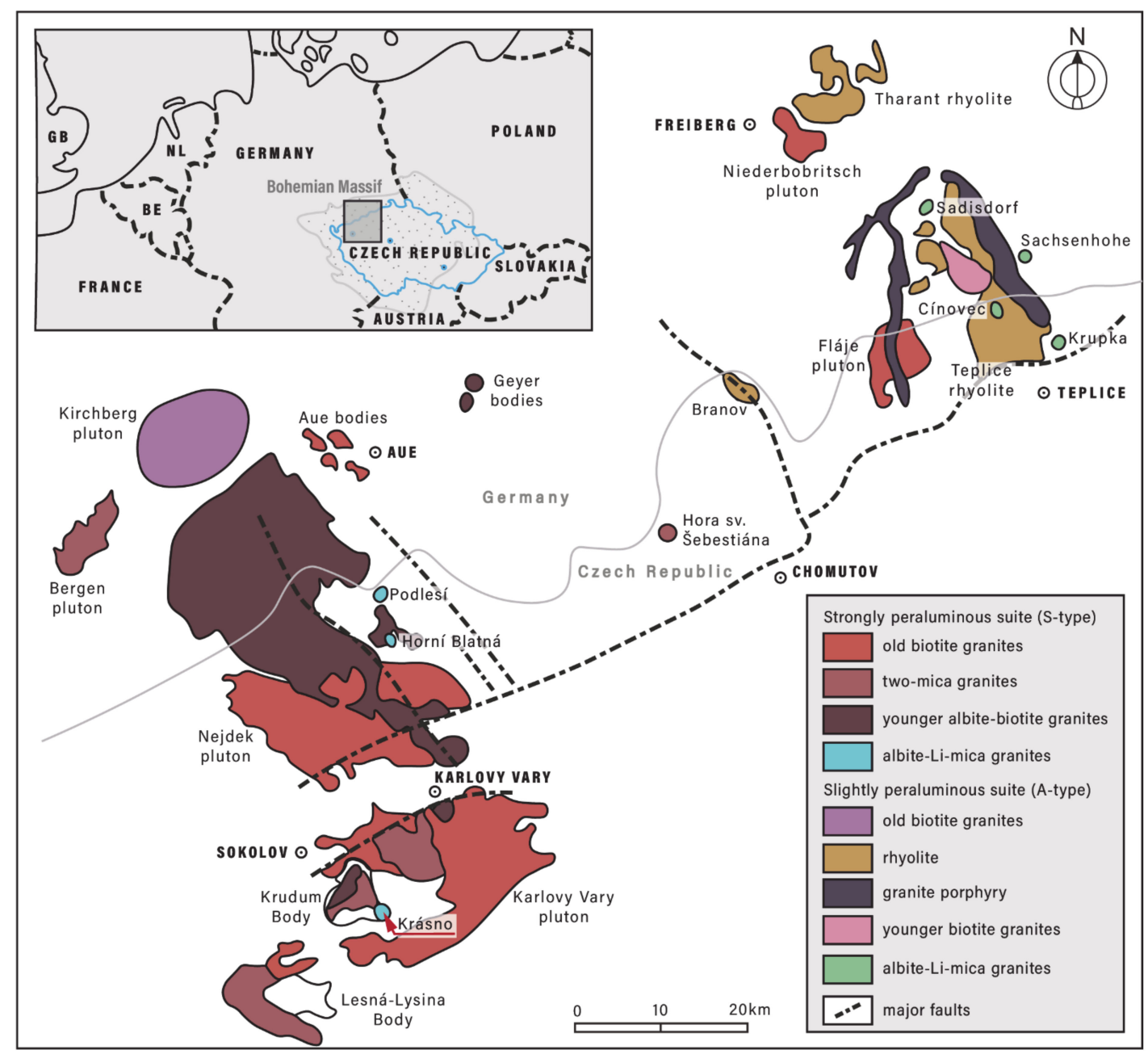

Figure 1. Sketch of Krušné hory/Erzgebirge Variscan granitic plutons. Studied locality Krásno forms part of Krudum body, which is located in the southern margins of the Karlovy Vary pluton (adopted and modified after [35]).

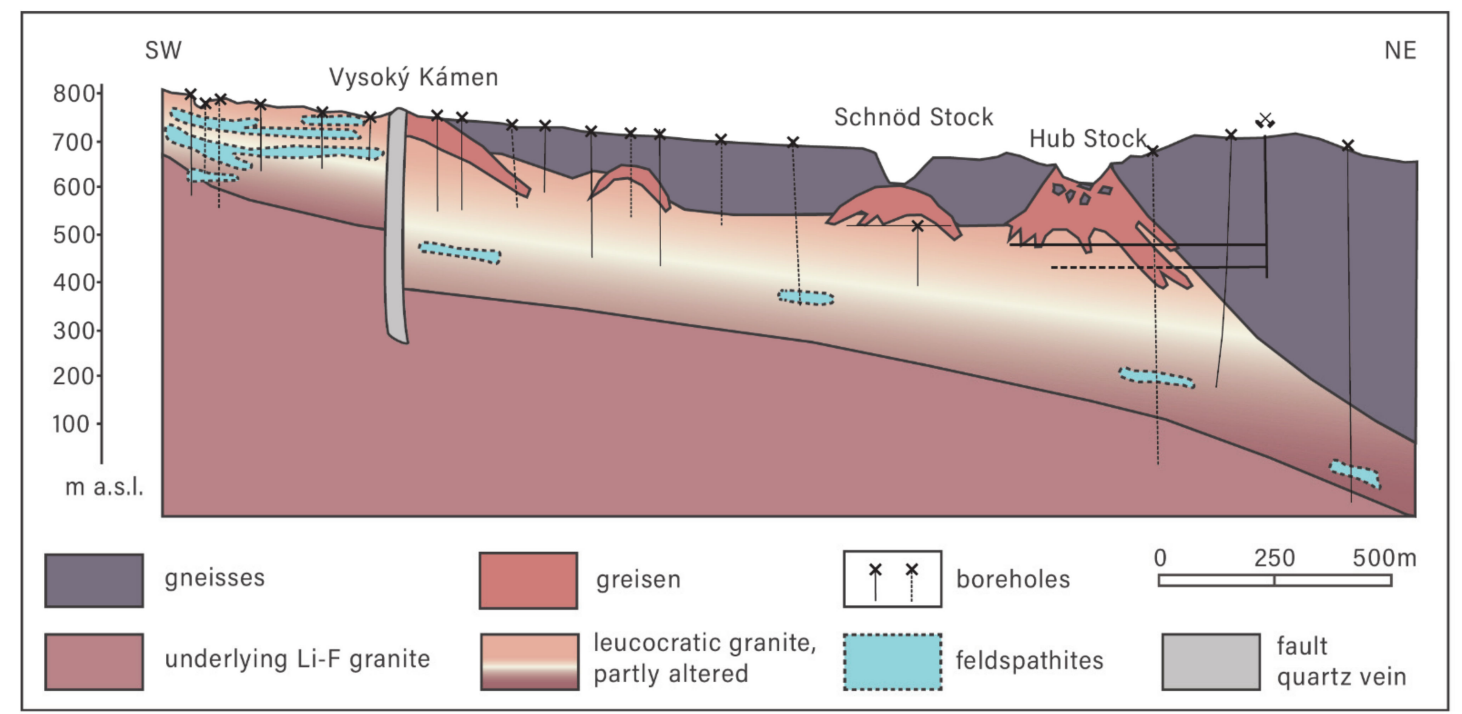

Figure 2. Cross-section through the Krásno-Horní Slavkov ore district (modified after [36]). Bodies of feldspathites intersected by exploratory drilling are probably not of strictly lenticular shape, but their lateral extent is unclear (marked dashed line). They might in fact present large sheet bodies as in the left side of the picture (modified after [36]). 
In general, the extracted raw material is referred to as alkaline-feldspar granite, leucogranite, albitic granite or even feldspathite (alkali-feldspar syenite [37]). Feldspars make the major rock-forming mineral with reported predominance of albite $(30-50 \%)$ over K-feldspar (20-30\%); however, they can make over $75 \%$ in feldspathite varieties. Quartz represents another major rock-forming phase (20-40\%). Content of micas (mostly Li-micas referred as Li-bearing muscovite, zinnwaldite or polylithionite) is highly variable from accessory to several percent. Some rock varieties can contain substantial part of topaz (up to $10 \%$ ), but its presence and distribution is highly variable [37]. In terms of other mineral phases, making mostly accessories, fluorapatite, rutile, ilmenite, monazite, xenotime and zircon are the most common. Most of these accessories are of special interest because they may act as colourants of the feldspar ore. Due to extensive signs of post-solidification hydrothermal activity which affected these rocks, presence of secondary phases, specifically clay minerals (kaolinite group minerals, smectites) and/or locally enriched zone of U-Th-bearing phases, makes another distinct feature of the feldspar ore rocks [38-41].

Due to rapid alternation between various subtypes (which is common feature of these hydrothermally modified granites), the feldspar ore is excavated (by blasting) as a whole, being further crushed, and screened. Only minor portion of the exploited material (currently around $1-1.5 \%$ of production) is milled, dedusted and classified by magnetic separation to basic marketed grades according mainly their chemistry (content of colourants).

As one of our goals was to evaluate material whose composition would represent the composition of the real product, the sample for the experimental study was obtained from normal production of the quarry. The experimental material was magnetically separated from the KMK Granite sister company-Czech Silicate. This magnetic separate originates from processing of daily production (conventionally from stock pile whose production from different parts of the quarry is deposited during 7-10 days). The input material is denominated as FK0-5 (Feldspar Krásno, size fraction $0 / 5 \mathrm{~mm}$ with average grain size: less than $0.063 \mathrm{~mm}=4.2 \%, 0.063-0.1 \mathrm{~mm}=1.7 \%, 0.1-0.63 \mathrm{~mm}=22.7 \%, 0.63-2 \mathrm{~mm}=33.1 \%$, and $2-5 \mathrm{~mm}=38.3 \%$. The homogenized mixture is then transported to Czech Silicate where it is further crushed, screened and milled to the final product exhibiting grain size below $1 \mathrm{~mm}$, with fraction below $0.1 \mathrm{~mm}$ less than $20 \%$. Such product is subject of magnetic separation (magnetic separator from Eriez Co. equipped with cylindrical permanent REE magnets). Magnetic separate is continually stored in big bags. One of them was sampled from the top to the bottom (i.e., vertically across any potential layers created during storing to achieve maximum possible homogeneity of the sample). The grain size distribution of studied material is less than $1 \mathrm{~mm}$, fraction $\leq 0.1 \mathrm{~mm}$ is up to $20 \%$. This sample was subsequently purified on an Eriez laboratory separator (Dry High Intensity Rare Earth Roll Magnetic Separator), and the obtained magnetic fraction, labelled as "Krásno M.S." (Krásno Magnetic Separate), served as input for further study.

\subsection{Separation Process}

The basic goal of laboratory separation procedure was to split the Krásno magnetic separate (Krásno M.S.) into individual mineralogical fractions, which represent typical minor/accessory admixtures to dominant feldspar-quartz matrix. The separation was based on two principal physical properties of present phases: magnetic properties and density. The separation flow-chart (Figure 3) then consists of logical steps, which gradually involve initial gravity separation by wet shaking table (WST), followed with magnetic separation of light fraction (WST-LF on Figure 3) and combined gravity and heavy liquid separations of heavy fraction (WST-HF on Figure 3). WST apparatus was older (from 1950s) machine used at the Czech Geological Survey (Prague, Czech Republic) (size: $95 \mathrm{~cm} \times 45 \mathrm{~cm} \times 35 \mathrm{~cm}$, feed pulp concentration: $1 \mathrm{~kg} / \mathrm{min}$, deck angle: $4^{\circ}$, stroke amplitude: $200 \mathrm{rpm}$ and water flow rate: $5 \mathrm{~L} / \mathrm{min}$ ). 


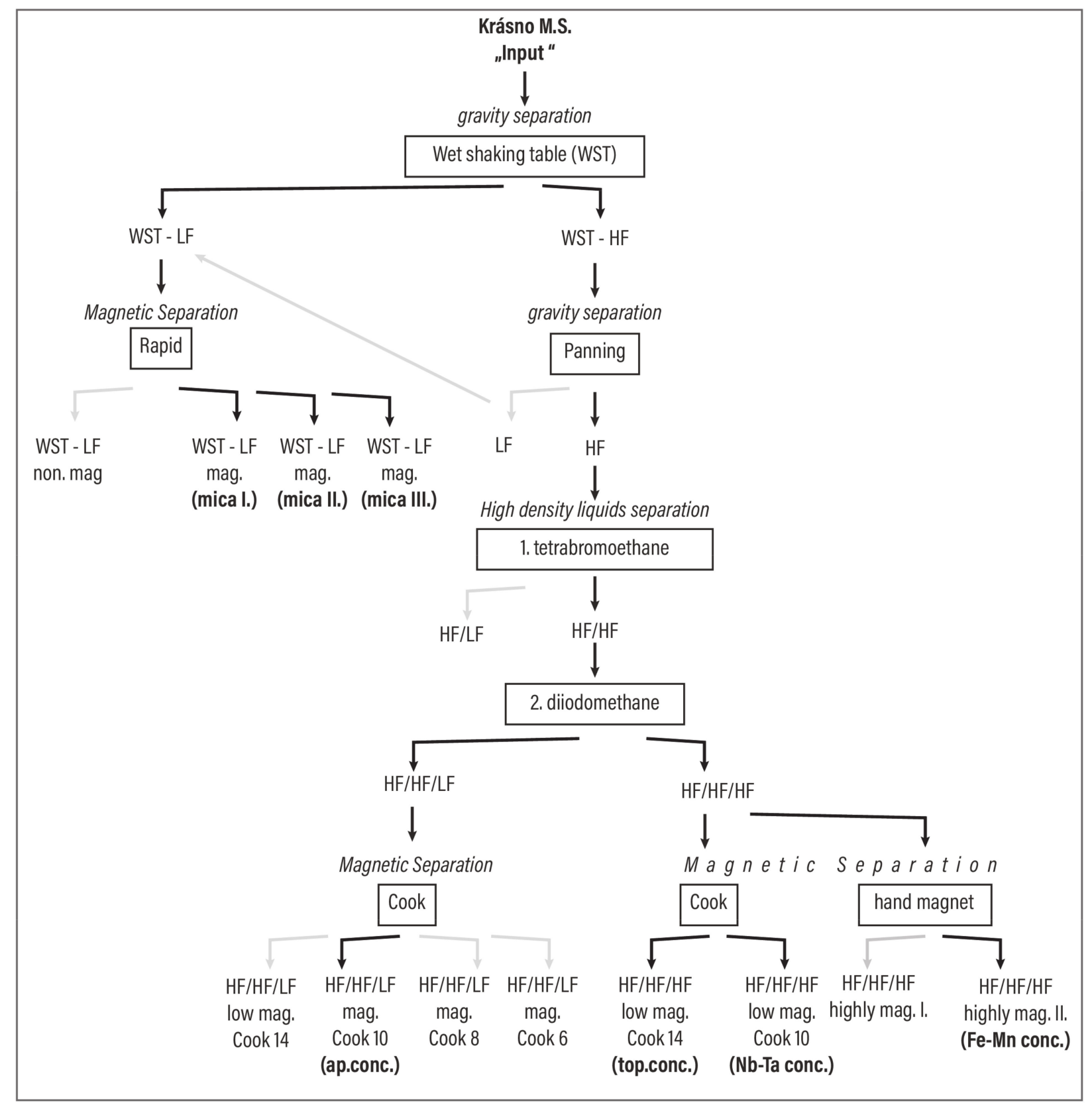

Figure 3. Flow-chart of laboratory separation procedure applied in the current study. The most important products of separation procedure, investigated in this study, are shown in bold.

Magnetic separation with magnetic flux density of 0.1-0.5 $\mathrm{T}$ was performed using another laboratory magnetic separator (Rapid, Czech Geological Survey, Prague, Czech Republic) of light fraction (WST-LF) resulted in non-magnetic light fraction composed of feldspar-quartz (this was not used further in the study) and three magnetic light fractions labelled as mica I, mica II, and mica III (Figure 3).

In the case of WST-HF fraction, this was again processed by gravity separation (panning) during which admixtures of light fraction were removed (Figure 3). Then, two-steps heavy liquid separation followed employing tetrabromoethane $\left(\mathrm{C}_{2} \mathrm{H}_{2} \mathrm{Br}_{4}\right)$ with density of $2.96 \mathrm{~g} / \mathrm{cm}^{3}$ and diiodomethane $\left(\mathrm{CH}_{2} \mathrm{I}_{2}\right)$ exhibiting density of $3.32 \mathrm{~g} / \mathrm{cm}^{3}$. Separation in tetrabromoethane resulted in lighter heavy fraction marked as HF/LF (i.e., fraction containing minerals that float due to density below $\left.2.96 \mathrm{~g} / \mathrm{cm}^{3}\right)$ and heavier heavy fraction marked as HF/HF (i.e., fraction containing minerals with density above $2.96 \mathrm{~g} / \mathrm{cm}^{3}$ ). Although HF/LF fraction was discarded, the HF/HF fraction was further processed with 
diiodomethane $\left(\mathrm{CH}_{2} \mathrm{I}_{2}\right)$, which resulted in lighter $\mathrm{HF} / \mathrm{HF}$ fraction (marked as $\mathrm{HF} / \mathrm{HF} / \mathrm{LF}$ on Figure 3) and in heavier fraction $\mathrm{HF} / \mathrm{HF} / \mathrm{HF}$.

HF/HF/LF fraction was further separated by Cook electromagnetic separator (by Chas. W. Cook \& Sons Ltd., late Manchester \& Ashby, Warley, England) with parameters: 0-250 V; 0-2.8 A; 0.1-1.2 T at Czech Geological Survey into 4 different samples, from which one was represented by apatite concentrate used in successive study. In the case of HF/HF/HF fraction, magnetic separation by either Cook electromagnetic separator and/or by hand magnet (ferrite permanent magnet: $0.1-0.3 \mathrm{~T}$, and/or $\mathrm{NdFeB}$ powder magnet produced by Magsy company: $0.8-1$ T, Fryšták, Czech Republic) was used to obtain three important output samples: topaz concentrate, $\mathrm{Nb}$-Ta concentrate and Fe-Mn concentrate.

The material balance during the whole separation process was carefully checked after each separation step. The input and output were weighted using laboratory balance Sartorius LA120S with capacity of $120 \mathrm{~g}$ with a readability of $0.1 \mathrm{mg}$.

\subsection{Chemical Analyses}

The analysed material (input sample) and principal output samples (obtained through above-mentioned separation process) were analysed for chemical composition using accredited procedure in KMK Granite laboratory, Krásno, Czech Republic. Ground homogenized specimens were pressed into pellets bound with cellulose. The analysis of selected elements (in oxide form) was done using XRF spectrometer (THERMO Scientific ARL PERFORM ${ }^{\prime} X$ at KMK Granite laboratory; samples were measured by the UniQuant method that represents complete analysis package for standardless semi-quantitative to quantitative XRF analysis using intensities measured by a sequential X-ray spectrometer.

\subsection{Phase Analyses}

For the phase analyses of studied specimens, powder X-ray diffraction (XRD) was used. The measurements were performed using Bruker D8 Advance powder X-ray diffractometer (Bruker, Billerica, MA, USA) in a Bragg-Brentano configuration. CuK $\alpha$ radiation and a position-sensitive detector with a Lynx Eye XE detector were used. Powder samples for X-ray diffraction were ground in a McCrone Mill grinder and the method of so-called lateral filling in plastic holders (PMMA) was prepared. Diffraction recording was taken in the angular range $4-80^{\circ} 2 \theta$ with a step of $0.015^{\circ} 2 \theta$ and a reading time of $0.8 \mathrm{~s}$ per step.

In the case of mica samples, placement of samples into $0.5 \mathrm{~mm}$ capillary and use of Göbel mirror was selected in order to diminish the effect of strong diffractions on basal planes of preferentially ordered phyllosilicates. XRD data were obtained using same equipment with following conditions: $8-65^{\circ} 2 \mathrm{Theta}$, step of $0.015^{\circ}$, counting time 1.5 s per step.

Records of X-ray diffraction were qualitatively evaluated in the program Difrrac Eva (Bruker AXS, 2015) using the PDF 2 (2002) database. Subsequent semiquantitative phase analysis was performed using the Rietveld method in the TOPAS 5 program (Bruker AXS, 2014). Models of crystal structures of individual phases were obtained from the ICSD database (FIZ 2015). During the Rietveld analysis, the scale factors of individual phases, their lattice parameters and the size of coherently diffracting domains were specified. Priority orientation correction was applied.

\subsection{Scanning Electron Microscopy with Microanalysis}

Selected fractions have been also examined for chemical composition using scanning electron microscopy with energy-dispersive spectrometry (SEM/EDS). In this case, part of separate was embedded in a resin and polished section was prepared. The analysis was performed using Tescan Vega instrument (Institute of Petrology and Structural Geology, Faculty of Science, Charles University, Prague, Czech Republic) with an energy-dispersive spectrometer X-Max 50 (Oxford Instruments, Oxford, UK) to obtain information about the chemistry of mineral phases. For selected grains, compositional elemental maps were obtained as well, allowing for plotting of the distribution of specific elements in the 
analysed part of the polished section. The measurements were conducted at an accelerating voltage of $15 \mathrm{kV}$ and beam $1.5 \mathrm{nA}$ (in the case of back-scatter electrons imaging (BSE)) and $15 \mathrm{kV}$ and current $6 \mathrm{nA}$ in the case of compositional elemental maps.

\section{Results}

The applied separation flow-chart (Figure 3) allowed for effective separation of nonmagnetic phases (dominant feldspar-quartz matrix with traces of micas) and magnetic or high-density phases (apatite, $\mathrm{Nb}$-Ta-rutile, Fe-Mn, topaz and mica fractions). Each fraction exhibits distinct chemical composition (Table 1) and mineralogical composition (Figure 4 and Table 2).

Table 1. Results of XRF analyses of respective fractions obtained during laboratory separation of Krásno feldspar ore (data in wt.\%) and their mass balance (m.b.) as a percentage of input material (Krásno M.S.). $\mathrm{Li}_{2} \mathrm{O}$ analyses (performed on mica samples only) was performed by AAS (Atomic absorption spectroscopy) method (VARIAN type SpectrAA 280 FS, Agilent, Santa Clara, USA). Typical composition (average value from analyses routinely performed on daily production during last 2 years) of the most common product (FK0-5) is provided for comparison. Note that topaz fraction was not analysed due to its very low content (about $0.01 \%$ ).

\begin{tabular}{|c|c|c|c|c|c|c|c|c|c|c|c|c|c|c|}
\hline Sample & $\mathrm{SiO}_{2}$ & $\mathrm{Al}_{2} \mathrm{O}_{3}$ & $\mathrm{Fe}_{2} \mathrm{O}_{3}$ & $\mathrm{MnO}$ & $\mathrm{TiO}_{2}$ & $\mathrm{Nb}_{2} \mathrm{O}_{3}$ & $\mathrm{Ta}_{2} \mathrm{O}_{5}$ & $\mathrm{CaO}$ & $\mathrm{P}_{2} \mathrm{O}_{5}$ & $\mathrm{Rb}_{2} \mathrm{O}$ & $\mathrm{Li}_{2} \mathrm{O}$ & $\mathrm{K}_{2} \mathrm{O}$ & $\mathrm{Na}_{2} \mathrm{O}$ & m.b./\% \\
\hline FK0-5 & 74.14 & 14.64 & 0.45 & - & 0.04 & - & - & 0.38 & 0.39 & 0.12 & - & 4.48 & 4.24 & - \\
\hline Krásno M.S. & 60.36 & 17.31 & 3.36 & 0.55 & 1.30 & 0.32 & 0.11 & 3.38 & 2.39 & 0.24 & - & 5.73 & 3.48 & 100 \\
\hline mica I. & 44.86 & 20.89 & 17.67 & 0.89 & 0.91 & 0.08 & 0.01 & 0.15 & 0.12 & 0.87 & 2.05 & 8.53 & 0.47 & 0.8 \\
\hline mica II. & 44.17 & 20.95 & 11.83 & 4.58 & 1.25 & 0.12 & 0.03 & 0.89 & 1.17 & 0.60 & 1.59 & 7.54 & 1.48 & 0.9 \\
\hline mica III. & 45.62 & 24.46 & 9.73 & 0.52 & 0.56 & 0.06 & 0.01 & 1.04 & 1.22 & 0.74 & 2.11 & 9.43 & 0.82 & 0.7 \\
\hline ap. conc. & 6.67 & 2.80 & 1.38 & 2.96 & 0.30 & 0.08 & 0.03 & 42.31 & 38.14 & 0.02 & - & 0.61 & 0.63 & 0.9 \\
\hline $\mathrm{Nb}$-Ta conc. & 9.49 & 4.14 & 5.91 & 1.07 & 51.16 & 11.26 & 5.99 & 3.23 & 3.73 & 0.01 & - & 0.62 & 0.55 & 0.5 \\
\hline Fe-Mn conc. & 15.36 & 0.69 & 31.78 & 9.47 & 11.69 & 2.60 & 1.56 & 7.49 & 7.76 & 0.04 & - & 1.30 & 1.42 & 0.7 \\
\hline
\end{tabular}

"-" denotes not analysed. ap.: Apatite

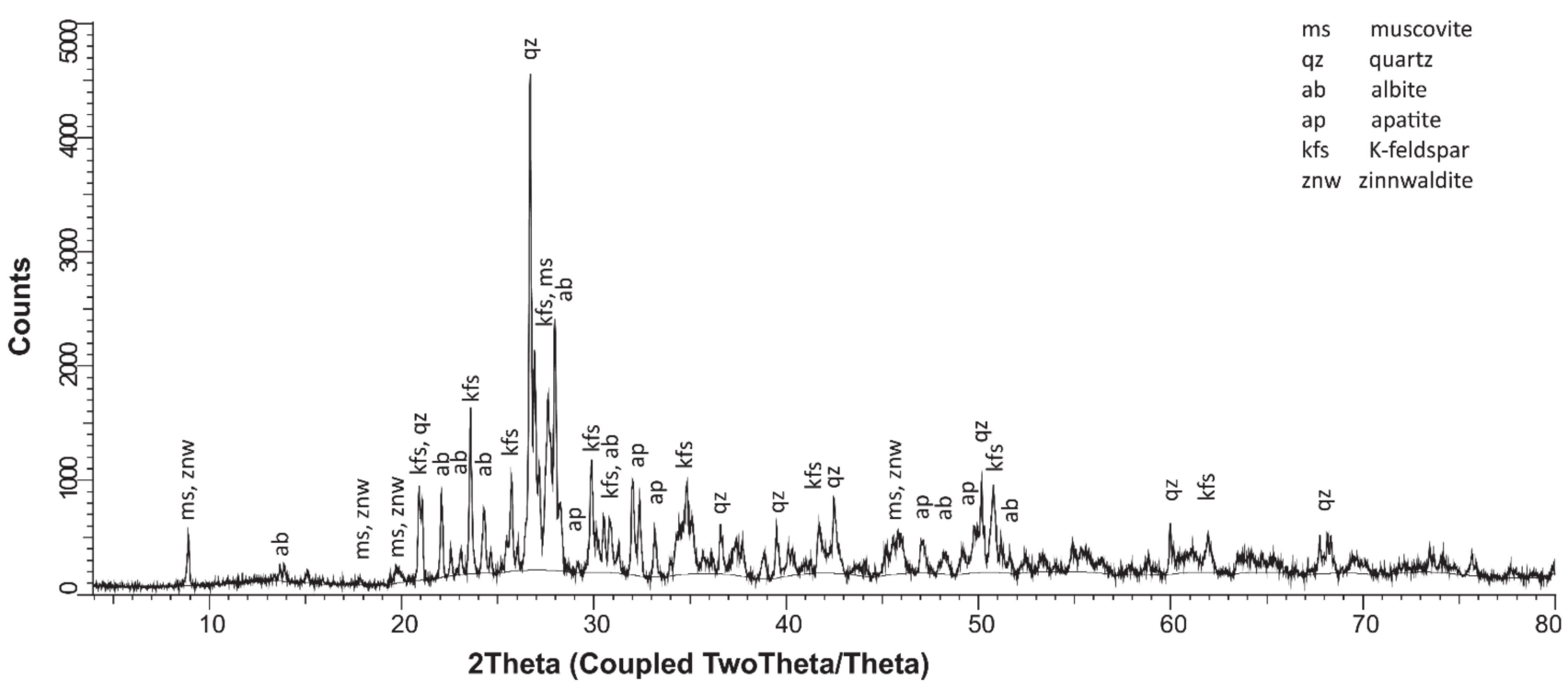

(a)

Figure 4. Cont. 


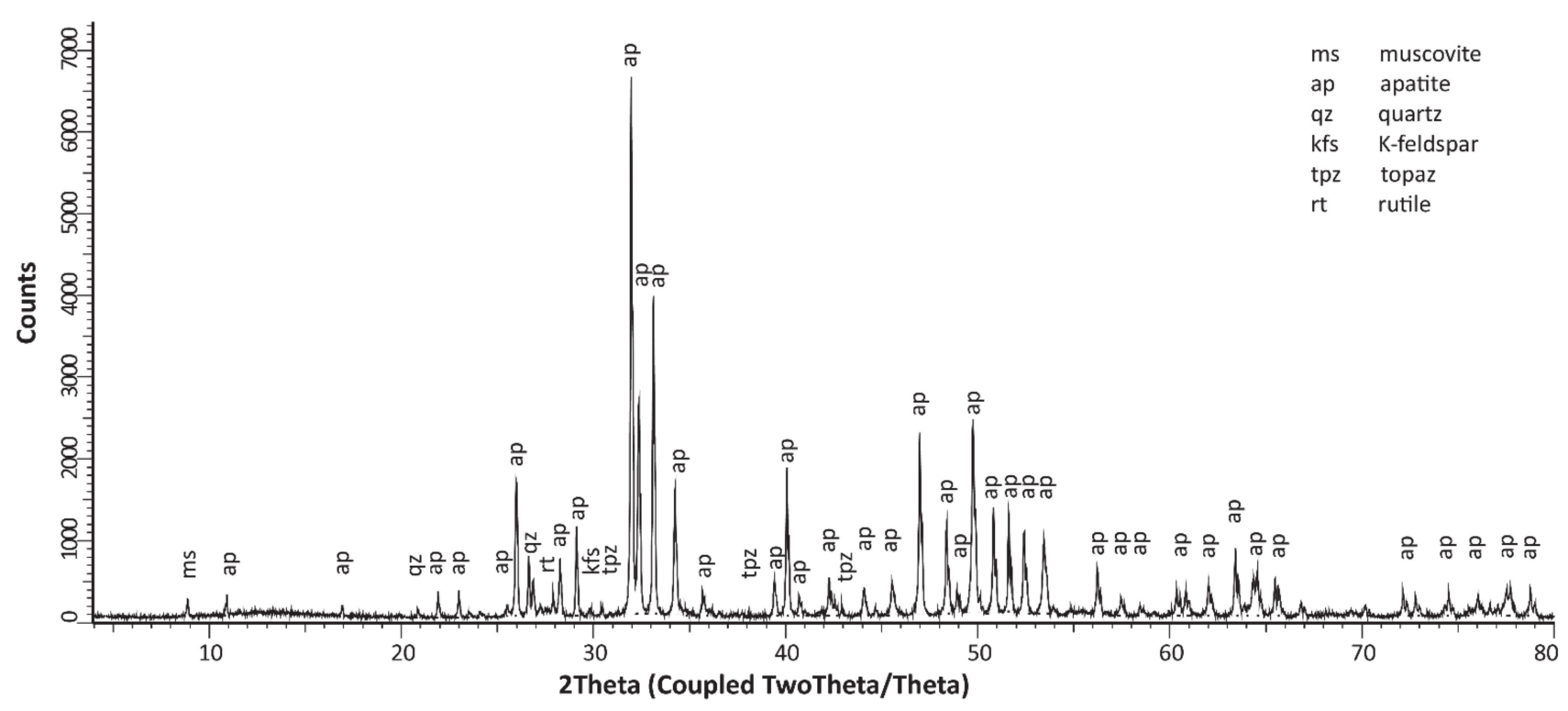

(b)

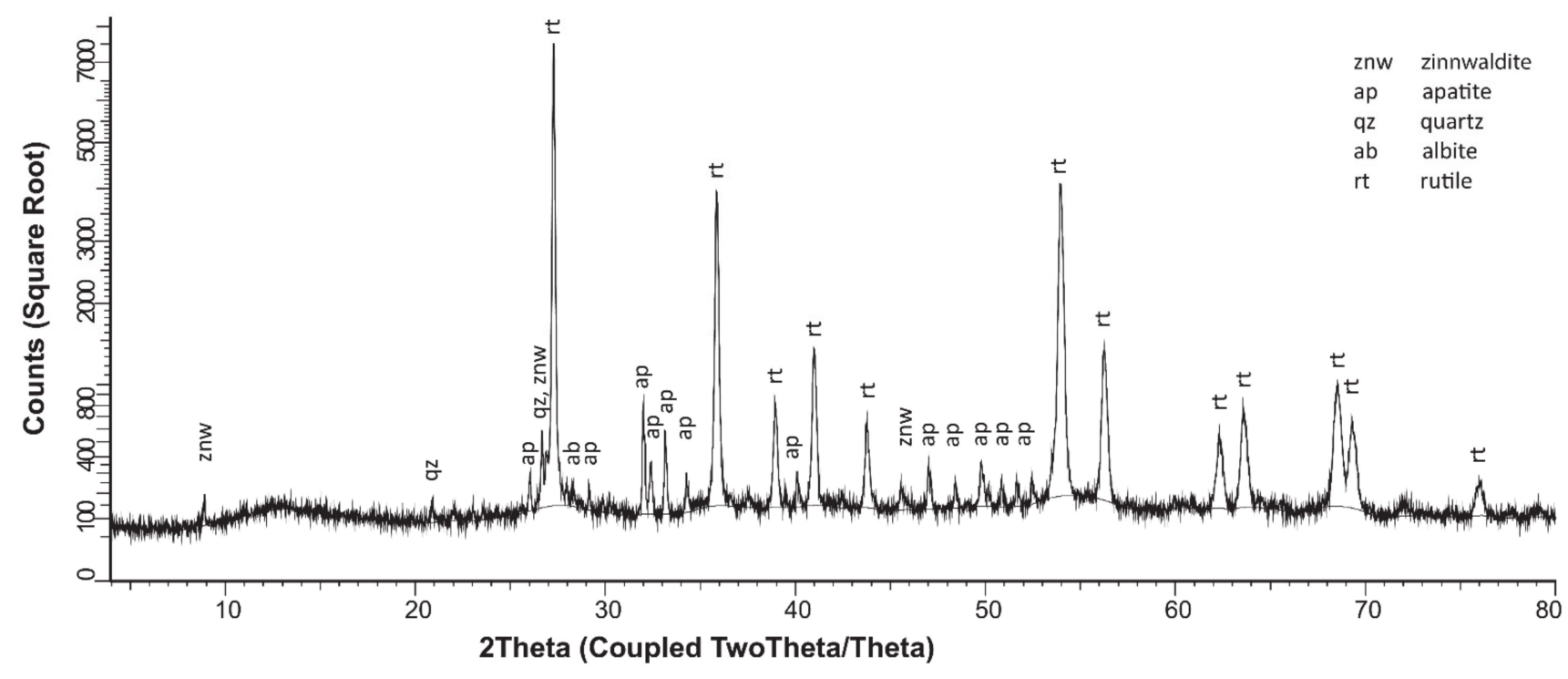

(c)

Figure 4. Cont. 


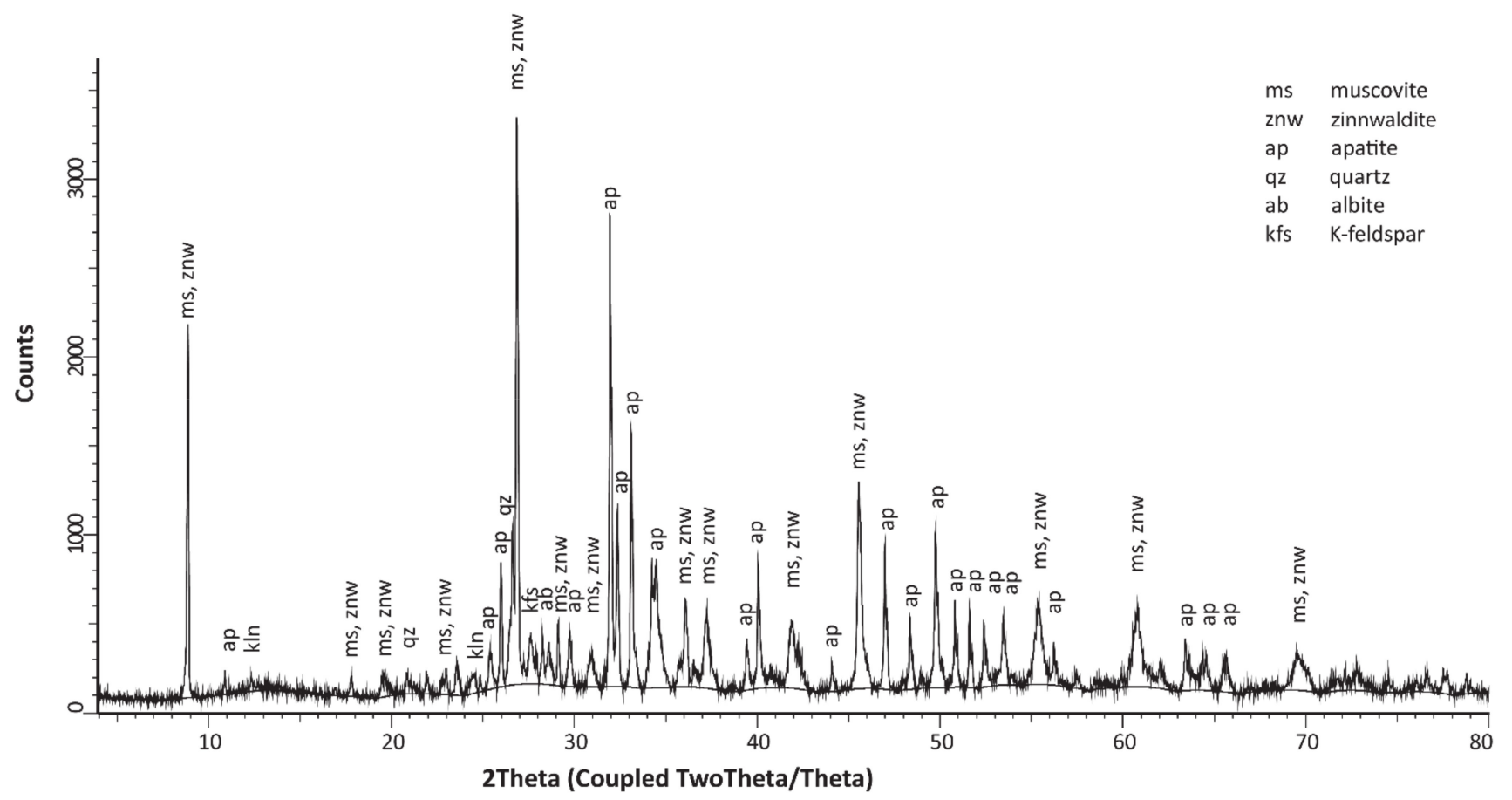

(d)

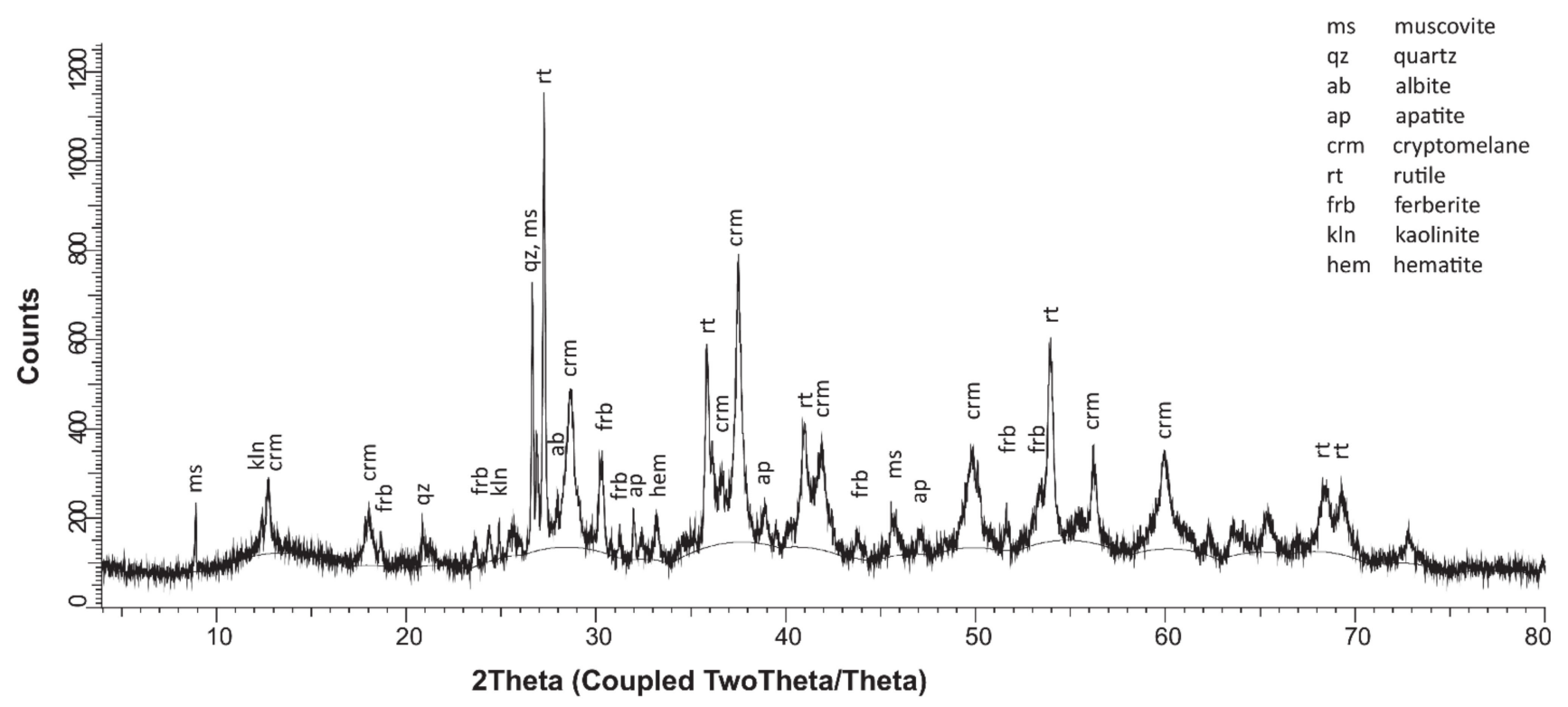

(e)

Figure 4. Cont. 


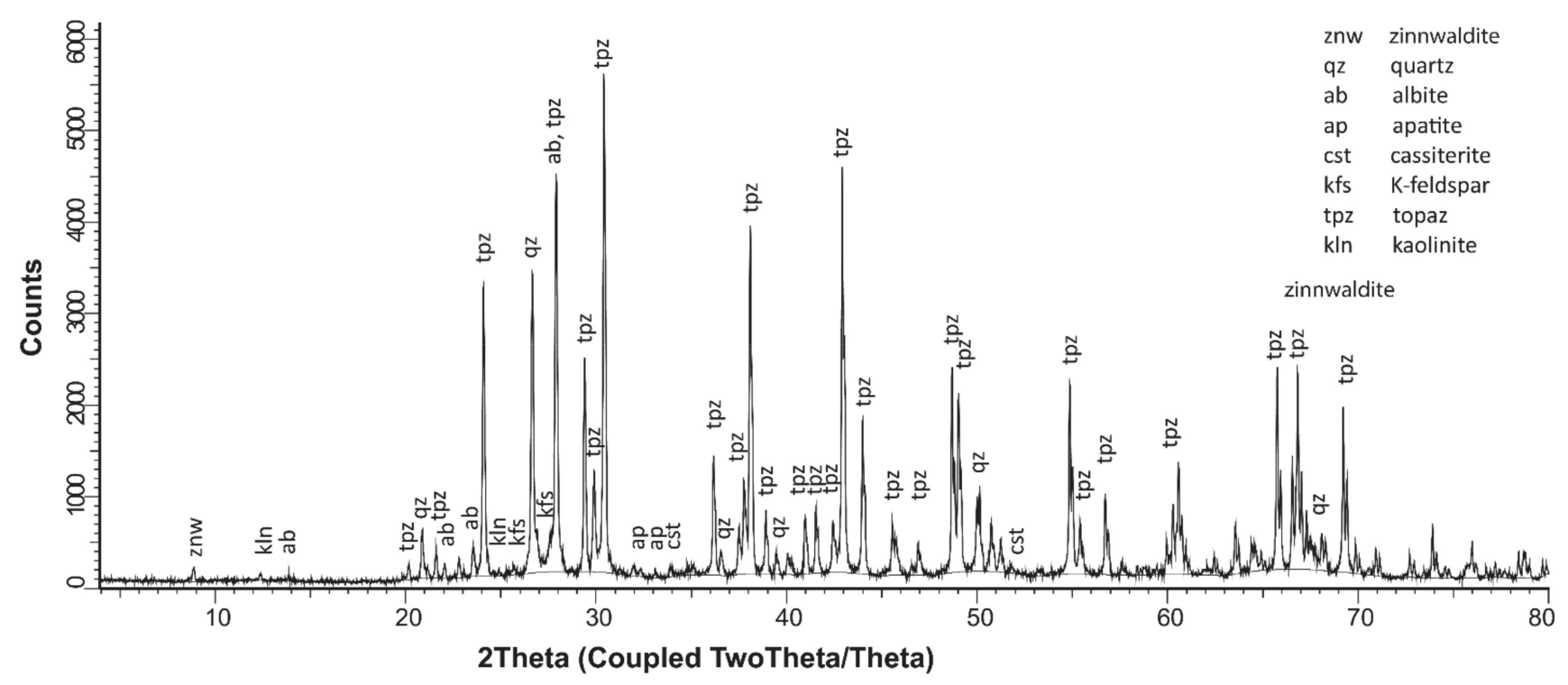

(f)

Figure 4. XRD patterns of: (a) wet shaking table followed with magnetic separation of light fraction (WST-LF), (b) ap. conc., (c) Nb-Ta conc., (d) mica II., (e) Fe-Mn conc., (f) top. conc. Used abbreviations are according to Whitney and Evans [42].

Table 2. Results semiquantitative determination of mineral phases in respective concentrate using Rietveld refinement. Qz = quartz, $\mathrm{Pl}$ = plagioclase (structural model of albite was used), Kfs = K-feldspar (structural model of microcline was used),

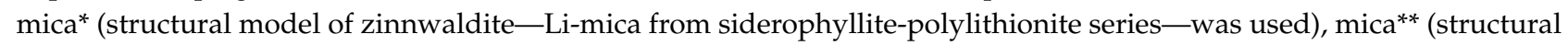
model of muscovite was used), Ap = apatite, Rt = rutile, Tpz = topaz, Wlf $=$ wolframite, $\mathrm{Crp}=$ cryptomelane, Hem $=$ hematite, $\mathrm{K} \ln =$ kaolinite.

\begin{tabular}{|c|c|c|c|c|c|c|c|c|c|c|c|c|}
\hline Sample & $\mathrm{Qz}$ & Pl & Kfs & Mica* & Mica** & Ap & $\mathbf{R t}$ & Tpz & Wlf & Crp & Hem & Kln \\
\hline Ap. conc. & 4 & - & 2 & - & 5 & 85 & 1 & 3 & - & - & - & - \\
\hline Fe-Mn conc. & 10 & 1.5 & - & - & 5 & 3 & 24 & - & 7 & 42 & 2 & 5.5 \\
\hline Mica II. & 5 & 4 & 6 & 22 & 26 & 35 & - & - & - & - & - & 2 \\
\hline Mica III. & 10.5 & 26 & 17 & 12 & 30 & 4 & - & - & - & - & - & 0.5 \\
\hline Nb-Ta conc. & 2 & 1 & - & 1 & - & 7 & 89 & - & - & - & - & - \\
\hline Tpz. conc. & 9 & 8.5 & 4.5 & 4 & - & 1 & - & 72 & - & - & - & 1 \\
\hline WST-LF, non-mag. & 16 & 29 & 33 & 5 & 9 & 8 & - & - & - & - & - & - \\
\hline
\end{tabular}

In the case of non-magnetic fraction (Figure 4a), quartz (well crystalline low $\alpha$ quartz) and feldspars (plagioclases represented by albite and alkali feldspars represented by Kfeldspar) make prevalent phases. Admixtures of micas (muscovite and zinnwaldite) and apatite were detectable as well. On the other hand, harmful colourants (Fe-Mn-bearing phases and $\mathrm{Nb}$-Ta-rich rutile) were effectively removed.

Apatite fraction obtained as a result of magnetic separation and two step heavy liquid separation is composed of dominant fluorapatite with negligible traces of micas (muscovite), quartz, K-feldspar (microcline), topaz, and rutile (Figure 4b). Apatite makes the most common accessory mineral of the leucocratic granite in the Krásno deposit [36] and is present in the form of isolated grains or as secondary filling of microcracks (Figure 5). Study performed on samples from this site indicates 0.26-0.40 apfu Mn in pure fluorapatite [43]. However, a large part of fluorapatite will be presented in the non-magnetic fraction. In our case, only apatites obtained from magnetic concentrate were studied. It turns out that they contain larger amounts of Mn (see Table 1, ap. conc.). Typical zonal texture (as observed by cathodoluminescence and SEM/EDS) is due to variable amount of manganese. Removal of apatite from feldspar ore thus presents one of significant steps on how to decrease content of one of the colouring elements. 

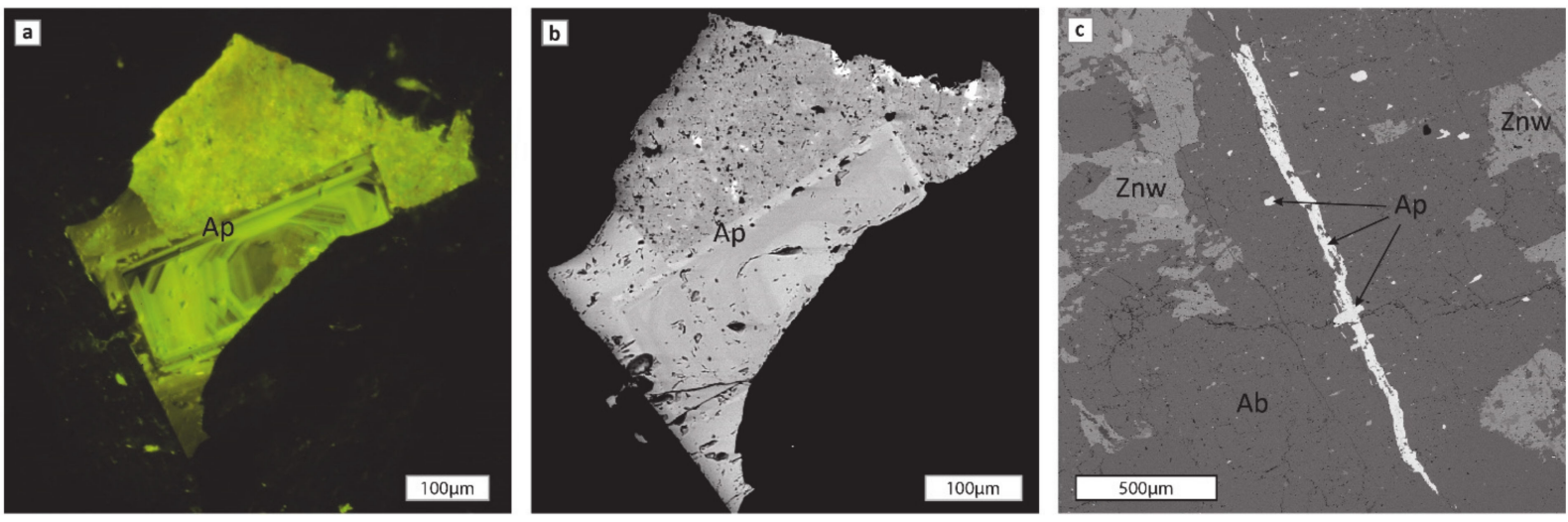

Figure 5. (a) Image of apatite in cathodoluminescence, (b) SEM (back-scatter electrons imaging (BSE)) image of zoned apatite, and (c) SEM (BSE) image of vein secondary filled by apatite. Explanation: Ap = apatite, Znw = zinnwaldite, $\mathrm{Ab}=$ albite.

$\mathrm{Nb}$-Ta-rich fraction is composed of dominant rutile (namely, $\mathrm{Nb}$-rich rutile) and $\mathrm{Nb}$ Ta-rich phases followed with minor/accessory admixtures of quartz, apatite, albite and zinnwaldite. Rutile is easily separated by heavy liquid separation due to its high-density $\left(4.23 \mathrm{~g} / \mathrm{cm}^{3}\right)$. According to SEM/EDS analyses and elemental compositional mapping, $\mathrm{Nb}$ and Ta are mostly concentrated in zoned rutile crystals (Figure 6a,b and Table 3). Based on performed analyses, apfu formula is $\left(\mathrm{Ti}_{0.86-0.93} \mathrm{Fe}_{0.04-0.08} \mathrm{Nb}_{0.03-0.06}\right) \mathrm{O}_{2}$. Nb-Ta oxides (columbite series) are much rarer, being often associated with much larger scheelite grains (Figure $7 \mathrm{a}, \mathrm{b}$ and Table 4).
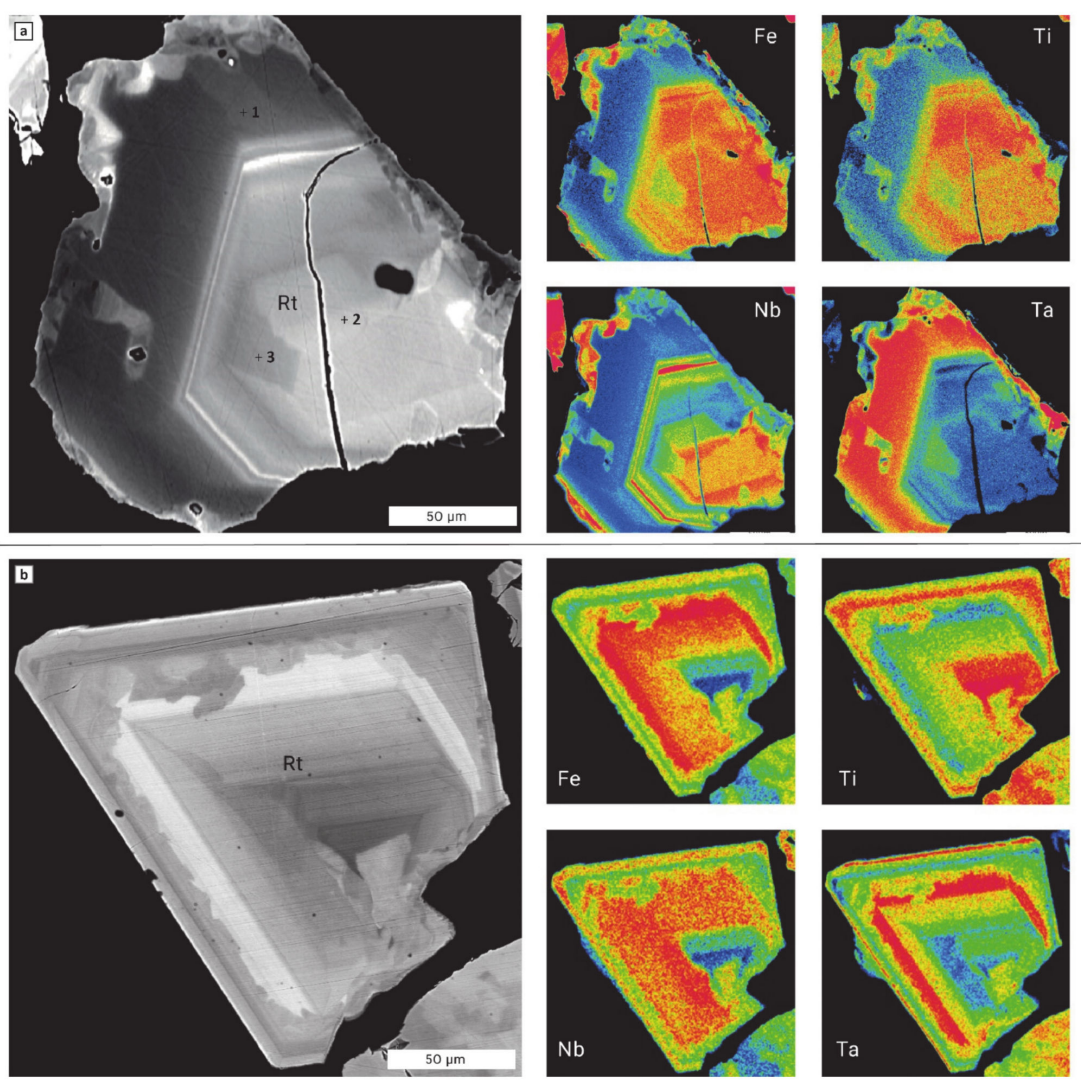

Figure 6. (a,b) SEM/energy-dispersive spectrometry (EDS)-BSE images of two Nb-Ta-rich rutile grains with characteristic zoning of $\mathrm{Fe}, \mathrm{Nb}, \mathrm{Ti}$, and $\mathrm{Ta}$ and their compositional maps. Explanation: $\mathrm{Rt}=$ rutile. Numbered crosses depict position of point chemical analyses (see Table 3 ). 
Table 3. Chemical composition of $\mathrm{Nb}$-Ta-rich rutile as determined by SEM/energy-dispersive spectrometry (EDS) (for position, see Figure 6a.)

\begin{tabular}{cccccccc}
\hline Analysis & $\mathrm{TiO}_{\mathbf{2}}$ & $\mathrm{Nb}_{\mathbf{2}} \mathrm{O}_{\mathbf{5}}$ & $\mathrm{Ta}_{\mathbf{2}} \mathrm{O}_{\mathbf{5}}$ & $\mathrm{FeO}$ & $\mathrm{MnO}$ & $\mathrm{SiO}_{\mathbf{2}}$ & Total \\
\hline $\mathbf{1}$ & 84.70 & 10.67 & 0.87 & 3.76 & 0.02 & 0.05 & 100.07 \\
$\mathbf{2}$ & 74.12 & 16.94 & 2.63 & 5.95 & 0.04 & 0.12 & 99.80 \\
$\mathbf{3}$ & 74.37 & 15.64 & 3.82 & 5.71 & 0.02 & 0.14 & 99.69 \\
\hline
\end{tabular}
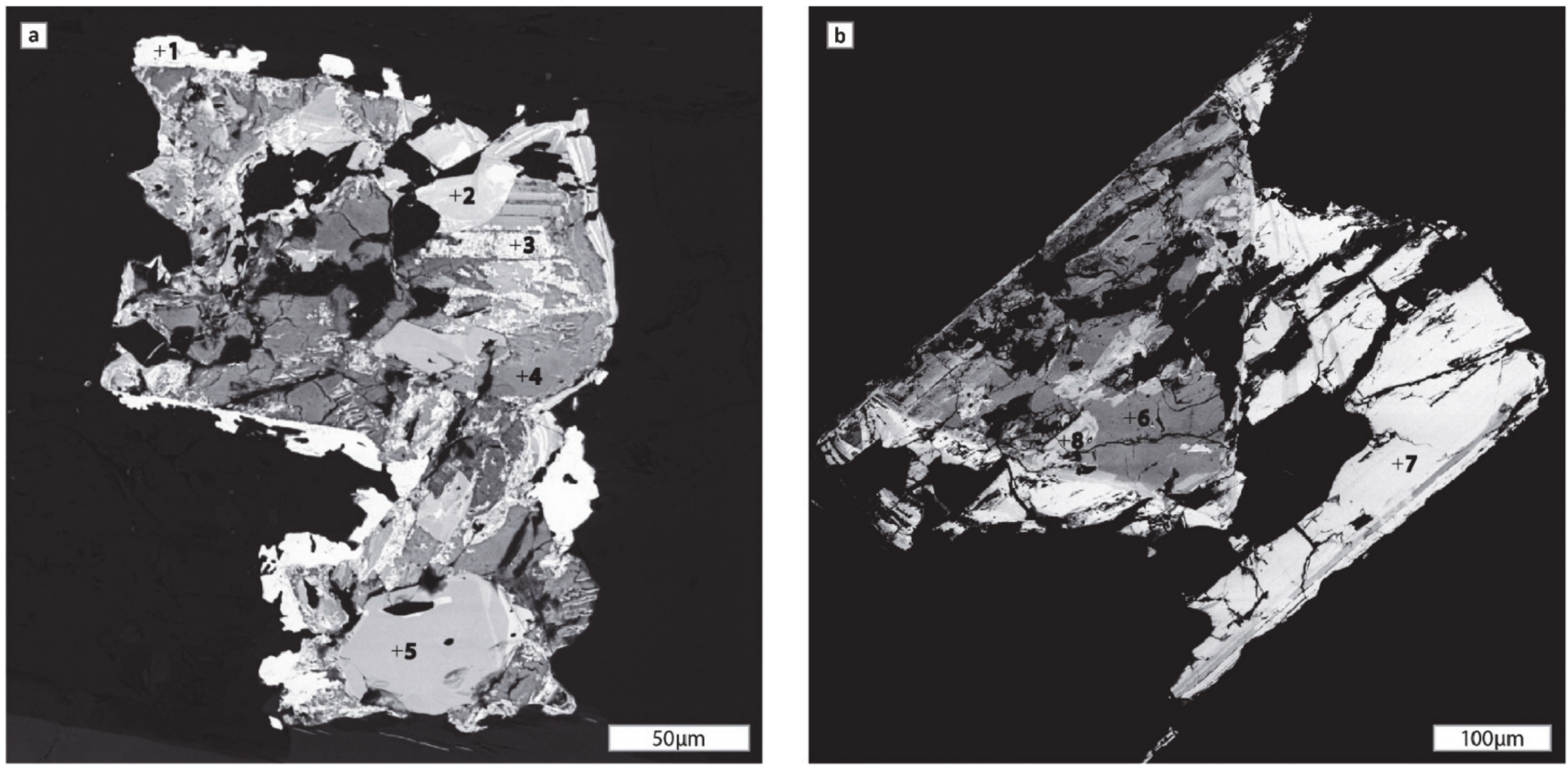

Figure 7. (a,b) SEM/EDS-BSE images showing position of Nb-Ta-rich phases belonging most likely to columbite family and their association with scheelite grains. Numbered crosses depict position of point chemical analyses (see Table 4).

Table 4. Chemical composition of Nb-Ta-rich phases as determined by SEM/EDS (for position, see Figure 6).

\begin{tabular}{ccccccccccccc}
\hline Analysis & $\mathbf{W O}_{\mathbf{3}}$ & $\mathrm{Ta}_{\mathbf{2}} \mathbf{O}_{\mathbf{5}}$ & $\mathbf{N b}_{\mathbf{2}} \mathbf{O}_{\mathbf{5}}$ & $\mathbf{T i O}_{\mathbf{2}}$ & $\mathbf{S i O}_{\mathbf{2}}$ & $\mathbf{S n O}_{\mathbf{2}}$ & $\mathbf{U}_{\mathbf{2}} \mathbf{O}$ & $\mathbf{B i}_{\mathbf{2}} \mathbf{O}_{\mathbf{3}}$ & $\mathbf{F e O}$ & $\mathbf{M n O}$ & $\mathbf{C a O}$ & $\mathbf{T o t a l}$ \\
\hline $\mathbf{1}$ & 80.40 & n.d & n.d & n.d & n.d & n.d & n.d & n.d & 0.43 & n.d & 19.35 & 100.91 \\
$\mathbf{2}$ & 33.96 & 9.66 & 12.72 & 2.23 & 1.73 & 1.98 & n.d & 6.2 & 16.41 & 4.68 & 0.45 & 90.01 \\
$\mathbf{3}$ & 67.85 & n.d & 3.14 & 0.66 & n.d & n.d & n.d & 1.63 & 4.07 & 0.97 & 15.07 & 93.49 \\
$\mathbf{4}$ & 13.83 & 16.52 & 17.37 & 2.66 & n.d & 1.72 & 2.02 & 7.56 & 12.98 & 2.09 & 0.56 & 77.33 \\
$\mathbf{5}$ & n.d & 12.41 & 64.80 & 2.01 & n.d & n.d & n.d & n.d & 16.06 & 3.73 & n.d & 99.01 \\
$\mathbf{6}$ & 37.71 & 7.79 & 18.43 & 2.57 & n.d & 2.51 & n.d & n.d & 18.69 & 3.94 & n.d & 91.65 \\
$\mathbf{7}$ & 69.24 & n.d & 3.71 & 0.30 & n.d & 0.61 & n.d & n.d & 19.16 & 4.56 & n.d & 97.58 \\
$\mathbf{8}$ & 56.05 & n.d & 9.66 & 1.11 & n.d & 1.60 & n.d & n.d & 17.77 & 4.69 & n.d & 90.87 \\
\hline
\end{tabular}

"n.d" means not detected.

Mica-rich fractions are represented mostly by Li-micas, i.e., zinnwaldite (Figures $4 \mathrm{~d}$ and 8 , associated with minor quartz, feldspars and apatite. Separation of zinnwaldite makes another significant processing step, which results in lowering of iron content. Further processing of mica fractions by magnetic separation (rapid magnetic separator) into three fractions proved that this method is highly sensitive to the content of iron in individual mica grains (Table 1).

Fe-Mn fraction is represented by high-density magnetic phases, being formed by Feoxides (hematite, followed with hydrated Fe-oxides) and Mn-rich phase being interpreted as cryptomelane from XRD data (Figure 4e). These dominant phases are accompanied with minor wolframite (ferberite) and rutile. Due to minute grain size of these phases and their common interlocking with quartz and/or feldspars, the latter two phases were present in 
this fraction as well and were easily detectable from XRD (Figure 4e) and from SEM/EDS (Figure 9). Some of Fe- or Mn-rich phases were mutually bound with clay minerals such as kaolinite (Figure 9). Fe-Mn fraction is also enriched in Fe-rich particles, which can be interpreted as a result of wear of jaws of the crusher.
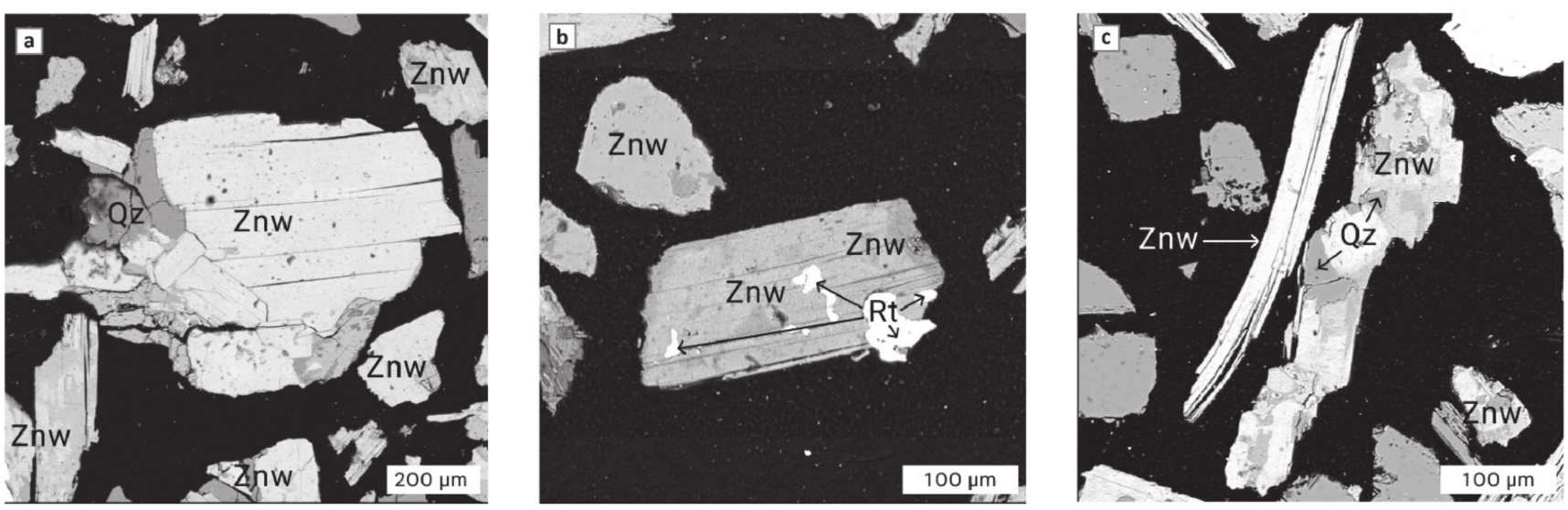

Figure 8. SEM/EDS-BSE images of Li-micas grains. Explanation: $\mathrm{Qz}=$ quartz, $\mathrm{Znw}=$ zinnwaldite, $\mathrm{Rt}=$ rutile. (a) zinnwaldite intergrown with quartz, (b) zinnwaldite with rutile, (c) zinnwaldite with quartz.
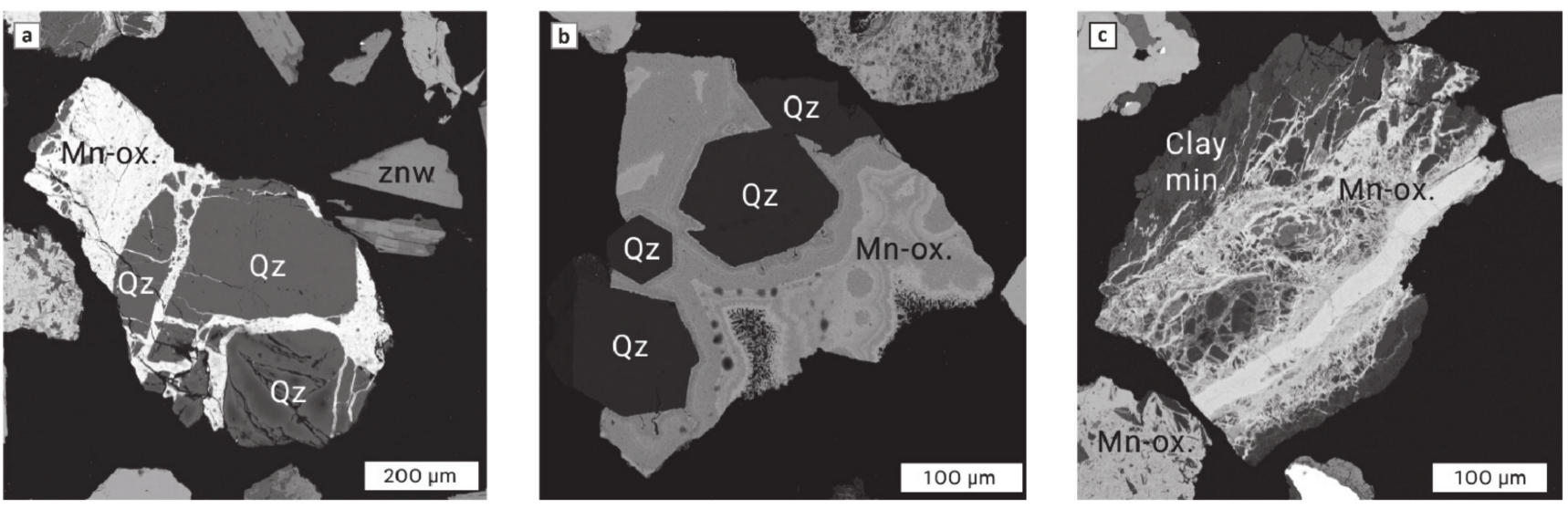

Figure 9. (a) SEM/EDS-BSE image of Mn-rich phase filling cracks in quartz grain, (b) quartz crystals cemented by botryoidal zoned manganese oxide overgrowth and (c) weathering products of the feldspars (kaolinite) and the iron-manganese phases. Explanation: $\mathrm{Qz}=$ quartz, $\mathrm{Mn}$-ox = Mn-rich oxides, Clay min. = clay minerals.

Topaz fraction makes one of the heavy fractions being separated through two-steps heavy liquid separation. Along with dominant topaz, some minor admixtures of other phases were detected by XRD (Figure 4f). Presence of topaz fraction in our processing flowchart is both due to its physical properties (high specific gravity) and common association with other minerals such as micas or rutile (Figure 10a,b). Topaz fraction is of low interest either considering its elemental composition or its harmful effect to the feldspar ore. Its content was very low (about $0.01 \%$ ) in the analysed material. 

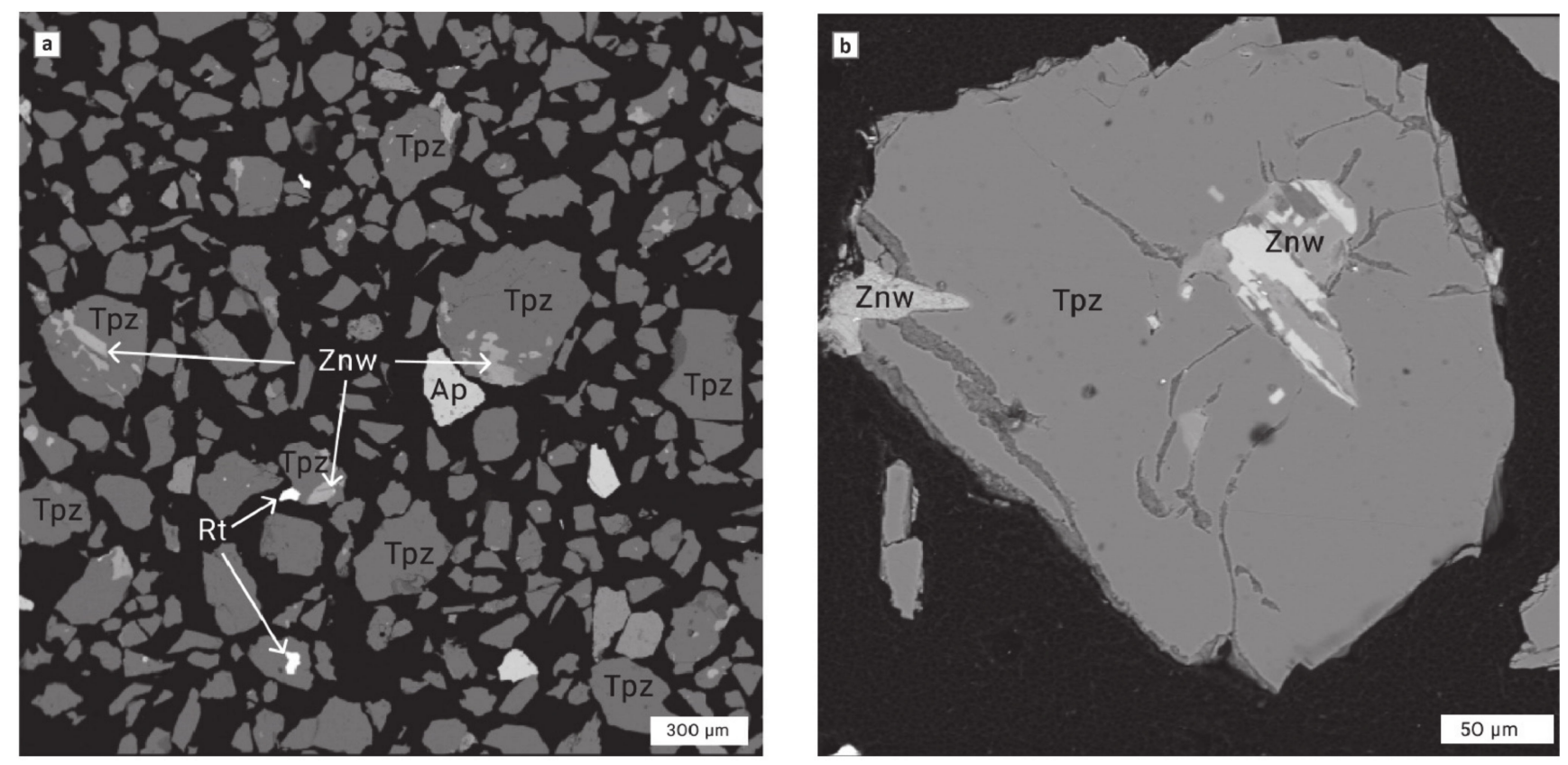

Figure 10. (a) SEM/EDS-BSE image of topaz concentrate and (b) topaz grain enclosing zinnwaldite (right). The topaz grain shows presence of distinct microfractures filled with kaolinite family clay mineral (probably dickite being associated with hydrothermal alteration of topaz [31]). Explanation: $\mathrm{Tpz}=$ topaz, $\mathrm{Rt}=$ rutile, $\mathrm{Ap}=$ apatite, $\mathrm{Znw}=$ zinnwaldite.

\section{Discussion}

\subsection{General}

Till now, majority of studies on processing and beneficiation of feldspar ore focused on removal of those phases which are considered as harmful colouring admixtures in ceramic/glass industries [44-47]. In order to make the beneficiation process effective and economic, any Fe-, Ti or Mn-bearing phase is considered as harmful. Due to chemi$\mathrm{cal} /$ physical properties of Fe-, Ti or Mn-bearing phases, combination of magnetic separation and flotation is considered to be most appropriate [15-18]; however, specifically flotation might have negative side effects on the environment [7]. A very few studies examined the possibility of re-processing of waste from feldspar ore or from feldspar rich rocks for their additional use in glass and/or ceramic industry [48-50]. Surprisingly, none of these studies focused on reversal approach-i.e., whether the phases removed during processing of feldspar raw material can be utilised as a potential valuable source of some critical or strategic mineral raw materials. This task might be of high practical interest as majority of feldspar ore exploited nowadays is due to the granites and hydrothermally altered granites [2], i.e., rock types similar to those from the investigated Krásno deposit.

The current study focused on the reverse problem - whether the waste obtained during the single-step industrial-scale processing (by magnetic separation) of feldspar ore can be effectively re-processed and employed as a source of valuable phases and/or elements. Multiple-step processing (combination of gravity, magnetic and heavy liquid separation) of the above-mentioned waste (magnetic separate) proved to be highly effective in obtaining compositionally distinct fractions (both in terms of phase and chemical composition). The laboratory-scale study aimed in the search for selection, combination, and hierarchy of processing methods, which might be effective in a planned industrial-scale multiple step processing of the feldspar ore. The purpose of such processing was twofold: (1) to improve processing of valuable raw material with the aim to obtain marketable material of higher purity (i.e., with lower content of colourants) and (2) to evaluate the possibility to employ part of the waste as a valuable by-product (i.e., materials that can be used as a source of CRMs). 


\section{2. $L i(+F e)$ Bearing Phases}

The main purpose of industrially applied processing scheme of feldspar ore from Krásno deposit is removal of phases containing colouring elements such as $\mathrm{Fe}$, $\mathrm{Ti}$ and $\mathrm{Mn}$. According to the results of the current study, major part of iron in the exploited feldspar ore is bound to Li-bearing micas, which can be generally classified as zinnwaldite (Li mica belonging to the siderophyllite and polylithionite series). Despite the variable content of these micas in various rock varieties composing the deposit (the highest content is for medium-grained leucogranite, the lowest content is for feldspathite/alkali feldspar syenite-[36]), Li-bearing micas represent the most abundant harmful admixture. In terms of the effectivity of separating methods, these can be easily removed by single-step magnetic separation.

Zinnwaldite is currently considered as an alternative source of Li, specifically in Central Europe due to widespread occurrences of Li-rich granites in East Germany and West Bohemia [51]. However, it must be noted that zinnwaldite represents lower quality Li ore than spodumene or lepidolite due to strong silicate framework, lower content of $\mathrm{Li}$ and enrichment in $\mathrm{F}$ and Fe [52-56].

Less amount of iron is bound to Fe-(oxy)hydroxides (or oxides) being more abundant in or close to distinct fault zones transecting the deposit. These zones can be effectively separated even during blasting of the raw material and do not present general problem in ore processing.

\subsection{Mn-Bearing Phases}

Regarding presence of manganese, two groups of phases are present. According to the results of this study, substantial part of $\mathrm{Mn}$ is bound to very common accessory phasefluorapatite. According to the chemical and SEM/EDS analyses, it contains significant admixtures of $\mathrm{Mn}$ with distinct zonal distribution. As this phase is widespread accessory in all rock varieties of the deposit, it must be separated as well. Fortunately, Mn-bearing apatite is easily separated by magnetic separation. This finding is in accordance with some recent studies on positive effect of $\mathrm{Mn}$ on apatite magnetic properties [57-59].

Along with apatite, $\mathrm{Mn}$ is locally enriched in some fault zones and/or on joint surfaces in the form of Mn-oxides from hollandite family [43,60]. According to our microscopic analysis, these phases make common secondary filling between grains of other rockforming minerals, often being associated with clay minerals. In addition, these minerals make part of bulk magnetic separate obtained during industrial-scale separation.

\subsection{Ti-(Nb-Ta)-Bearing Phases and Their Economical Potential}

Rutile, $\mathrm{Nb}$-Ta-rich rutile and subordinate $\mathrm{Nb}$-Ta oxides (columbite family) make another typical accessory of the investigated deposit. Due to the complex history of hydrothermal alteration that affected the investigated material, the $\mathrm{Nb}$-Ta enriched rutile phases exhibit complex zonal fabric and common intergrowths with other Fe-rich phases or other ore minerals (e.g., scheelite, wolframite, etc.), which are typical for the whole Horní Slavkov-Krásno ore district [29,37]. Fortunately, common presence of Fe-enriched phases in $\mathrm{Nb}$-Ta-rich rutile allows for their easy magnetic separation.

In terms of the quality of the discussed feldspar ore from Krásno deposit, $\mathrm{Nb}$-Ta-Ti mineral phases are currently considered as harmful colourant in the processing scheme and are removed as a part of bulk waste during dry magnetic separation of certain part of exploited material (such processing is applied for about $25 \%$ of the exploited feldspar ore at present, but extension of processing capacity for another $25 \%$ is in construction). In terms of current annual production (approximately $250 \mathrm{kt}$ ), about $125 \mathrm{kt}$ of feldspar ore thus will be processed by magnetic separation. Such separation would generate about $2.5 \mathrm{kt}$ of magnetic separate (considering content of separable magnetic fraction of $2 \%$ ), processing of which would gain some $12 \mathrm{t}$ of $\mathrm{Nb}$-Ta concentrate (about two-third of this amount is due to $\mathrm{Nb}$-phases). However, planned extension of the quarry operation laterally (this is necessary prior the quarry can go deeper) will require exploitation of surficial parts of the 
deposit, which contain 5-6\% of colourants (phase/elemental distribution and proportions are similar to that one in our study according to the unpublished data from analysis of drill hole specimens). Processing of such material can logically provide two to three times higher amounts of $\mathrm{Nb}$-Ta concentrate compared to the material studied by us.

Despite relatively low bulk tonnage expected from this novel source (recent world production is about $78 \mathrm{kt}$ of $\mathrm{Nb}$ and $1.8 \mathrm{kt}$ of $\mathrm{Ta}$ ), the main advantage of the proposed $\mathrm{Nb}$-Ta source would be its ease of obtaining from already exploited raw material. Another advantage can be seen in the fact that Krásno deposit can provide one of the very few economical sources of $\mathrm{Nb}$-Ta elements in European Union for which these elements make one of the most demanded CRMs [61,62].

It must be also noted that potential adoption of such processing scheme for similar feldspar deposits within Europe could increase EU-based $\mathrm{Nb}$-Ta sources to even higher levels. Other sources of $\mathrm{Nb}$, Ta and some other CRMs (e.g., REE, Sn) could be probably obtained from similar Variscan granites which underwent kaolinization [63-65].

The abundance of $\mathrm{Nb}$-Ta-rich phases at the studied deposit raises a question whether the current processing waste could be used, at least partly, as a potential source of valuable "critical raw materials". To solve this problem, we have applied the above-described multiple-step processing scheme to be able to obtain more enriched $\mathrm{Nb}$-Ta concentrate.

According to the preliminary results of the applied laboratory processing scheme, it seems that the used approach is generally promising, but its main disadvantage is connected with the use of heavy liquid separation step. As this approach is hardly applicable on industrial scale, our further effort will be focused on the use of some alternative methods on semi-industrial or industrial-scale trials.

\section{Conclusions}

Laboratory-scale experiment on additional processing of the waste generated during beneficiation of feldspar ore from Krásno deposit proved that proposed scheme (physical and chemical processing steps by combination of gravity, magnetic and heavy liquid separation) is highly effective in terms of obtaining mineralogically homogenous fractions. At least part of the obtained fractions can be considered as valuable by-product-source of critical raw materials. This specifically concerns the fractions enriched in Li-micas and/or $\mathrm{Nb}$-Ta-Ti mineral phases.

Despite successful obtaining of $\mathrm{Li}$ and/or $\mathrm{Nb}$-Ta concentrates, the main disadvantage of current processing scheme is connected with the use of heavy liquid separation step. As this approach is hardly applicable on industrial scale, our further effort will be focused on the use of some alternative methods on semi-industrial or industrial-scale trials.

Author Contributions: T.V. designed and performed the experiments; T.V. and R.P. analysed the data, wrote the paper. The paper makes part of Ph.D. study of T.V. supervised by R.P. All authors have read and agreed to the published version of the manuscript.

Funding: The financial support to this study from the Grant Agency of Charles University in Prague (Project No. GAUK 1352218) is highly acknowledged.

Data Availability Statement: As the study was conducted on material from private company, the available data are included in the published version of the papwer. The rest of the data are considered as datasets not available to general public.

Acknowledgments: We are also grateful for logistics, additional financial support and access to analytical techniques (XRF) and analytical support KMK GRANIT company.

Conflicts of Interest: The authors declare no conflict of interest.

\section{References}

1. Dondi, M. Compositional parameters to evaluate feldspathic fluxes for ceramic tiles. Tile Brick Int. 1994, 10, 77-83.

2. Dondi, M. Feldspathic fluxes for ceramics: Sources, production trends and technological value. Resour. Conserv. Recy. 2018, 133, 191-205. [CrossRef]

3. Kyonka, J.C.; Cook, R.L. The properties of feldspars and their use in whitewares. Univ. Ill. Bull. 1954, 422, 5-34. 
4. Zanelli, C.; Raimondo, M.; Guarini, G.; Dondi, M. The vitreous phase of porcelain stoneware: Composition, evolution during sintering and physical properties. J. Non Cryst. Solids 2011, 357, 3251-3260. [CrossRef]

5. Bernasconi, A.; Marinoni, N.; Pavese, A.; Francescon, F.; Young, K. Feldspar and firing cycle effects on the evolution of sanitaryware vitreous body. Ceram. Int. 2014, 40, 6389-6398. [CrossRef]

6. $\quad$ Singer, F.; Singer, S.J. Industrial Ceramics; Oxford \& IBH: New Delhi, India, 1963; p. 1431.

7. Zhang, Y.; Hu, Y.; Sun, N.; Liu, R.; Wang, Z.; Wang, L.; Sun, W. Systematic review of feldspar beneficiation and its comprehensive application. Miner. Eng. 2018, 128, 141-152. [CrossRef]

8. Karaguzel, C.; Gulgonul, I.; Demir, C.; Cinar, M.; Celik, M.S. Concentration of K-feldspar from a pegmatitic feldspar ore by flotation. Int. J. Miner. Process. 2006, 81, 122-132. [CrossRef]

9. Karagüzel, C.; Çobanoğlu, G. Stage-wise flotation for the removal of colored minerals from feldspathic slimes using laboratory scale Jameson cell. Sep. Purif. Technol. 2010, 74, 100-107. [CrossRef]

10. Bayat, O.; Arslan, V.; Cebeci, Y. Combined application of different collectors in the floatation concentration of Turkish feldspars. Miner. Eng. 2006, 19, 98-101. [CrossRef]

11. Kangal, O.; Guney, A. Beneficiation of low-grade feldspars using free jet flotation. Miner. Proc. Extr. Met. Rev. 2002, 23, 129-140. [CrossRef]

12. Filippov, L.O.; Severov, V.V.; Filippova, I.V. An overview of the beneficiation of iron ores via reverse cationic flotation. Int. J. Miner. Process. 2014, 127, 62-69. [CrossRef]

13. Heyes, G.W.; Allan, G.C.; Bruckard, W.J.; Sparrow, G.J. Review of flotation of feldspar. Miner. Proc. Extr. Met. 2012, 121, 72-78. [CrossRef]

14. Amarante, M.A.; Botelho, D.S.; Machado Lette, A. Beneficiation of a feldspar ore for application in the ceramic industry. J. S. Afr. I. Min. Metall. 1997, 97, 193-196.

15. El-Rehiem, F.H.; Abd El-Rahman, M.K. Removal of colouring materials from Egyptian albite ore. Miner. Proc. Extr. Met. 2008, 117, 171-174. [CrossRef]

16. Saisinchai, S.; Boonpramote, T.; Meechumna, P. Upgrading feldspar by WHIMS and flotation techniques. Eng. J. 2015, 19, 83-92. [CrossRef]

17. Ahmed, M.M.; Ibrahim, G.A.; Rizk, A.M.E.; Mahmoud, N.A. Reduce the iron content in Egyptian feldspar ore of Wadi Zirib for industrial applications. Int. J. Min. Eng. Miner. Process. 2016, 5, 25-34.

18. Alimon, M.M.; Ahmad, N. Malaysian feldspar: Evaluation and processing of selected deposits. J. Eng. Sci. 2011, 7, 27-35.

19. Štyriaková, I.; Štyriak, I.; Malachovský, P.; Lovás, M. Biological, chemical and electromagnetic treatment of three types of feldspar raw materials. Miner. Eng. 2006, 19, 348-354. [CrossRef]

20. Bernard-Griffiths, J.; Peucat, J.J.; Sheppard, S.; Vidal, P. Petrogenesis of Hercynian leucogranites from the southern Armorican Massif: Contribution of $\mathrm{REE}$ and isotopic $(\mathrm{Sr}, \mathrm{Nd}, \mathrm{Pb}$ and $\mathrm{O}$ ) geochemical data to the study of source rock characteristics and ages. Earth Planet. Sci. Lett. 1985, 74, 235-250. [CrossRef]

21. Moghazi, A.M.; Hassanen, M.A.; Mohamed, F.H.; Ali, S. Late Neoproterozoic strongly peraluminous leucogranites, South Eastern Desert, Egypt-petrogenesis and geodynamic significance. Mineral. Petrol. 2004, 81, 19-41. [CrossRef]

22. Vidal, P.; Bernard-Griffiths, J.; Cocherie, A.; Le Fort, P.; Peucat, J.J.; Sheppard, S.M.F. Geochemical comparison between Himalayan and Hercynian leucogranites. Phys. Earth Planet. Inter. 1984, 35, 179-190. [CrossRef]

23. Somarin, A.K.; Ashley, P. Hydrothermal alteration and mineralisation of the Glen Eden Mo-W-Sn deposit: A leucogranite-related hydrothermal system, Southern New England Orogen, NSW, Australia. Miner. Depos. 2004, 39, $282-300$.

24. Xie, L.; Tao, X.; Wang, R.; Wu, F.; Liu, C.; Liu, X.; Li, X.; Zhang, R. Highly fractionated leucogranites in the eastern Himalayan Cuonadong dome and related magmatic Be-Nb-Ta and hydrothermal Be-W-Sn mineralization. Lithos 2020, $354,105286$. [CrossRef]

25. Zahradník, J.; Jirásek, J.; Starý, J.; Sivek, M. Production, Reserves, and Processing of Feldspar and Feldspathoid Rocks in the Czech Republic from 2005 to 2019-An Overview. Minerals 2020, 10, 722. [CrossRef]

26. Massari, S.; Ruberti, M. Rare earth elements as critical raw materials: Focus on international markets and future strategies. Resour. Policy 2013, 38, 36-43. [CrossRef]

27. Hayes, S.M.; McCullough, E.A. Critical minerals: A review of elemental trends in comprehensive criticality studies. Resour. Policy 2018, 59, 192-199. [CrossRef]

28. Finger, F.; Gerdes, A.; René, M.; Riegler, G. The Saxo-Danubian granite belt: Magmatic response to post-collisional delamination of mantle lithosphere below the south-western sector of the Bohemian Massif (Variscan orogen). Geol. Carpath. 2009, 60, 205-212. [CrossRef]

29. René, M. REE and Y mineralogy of the Krudum granite body (Saxothuringian zone). Minerals 2018, 8, 287. [CrossRef]

30. René, M. Origin of topaz-bearing granites of the Saxothuringian Zone (Bohemian Massif). J. Geosci. 2003, 48, 112-113.

31. René, M. Composition of coexisting zircon and xenotime in rare-metal granites from the Krušné hory/Erzgebirge Mts. (Saxothuringian Zone, Bohemian Massif). Miner. Petrol. 2014, 108, 551-569. [CrossRef]

32. Št'astný, M.; René, M. Argillization of topaz-bearing granites in the Hub stock, Horní Slavkov-Krásno Sn-W ore district (Bohemian Massif, Czech Republic). Acta Geodyn. Geomater. 2014, 11, 255-267. [CrossRef]

33. Dolníček, Z.; René, M.; Prochaska, W.; Kovář, M. Fluid evolution of the Hub Stock, Horní Slavkov-Krásno Sn-W ore district, Bohemian Massif, Czech Republic. Miner. Depos. 2012, 47, 821-833. [CrossRef] 
34. Štemprok, M.; Blecha, V. Variscan Sn-W-Mo metallogeny in the gravity picture of the Krušné hory/Erzgebirge granite batholith (Central Europe). Ore Geol. Rev. 2015, 69, 285-300. [CrossRef]

35. Breiter, K. Nearly contemporaneous evolution of the A-and S-type fractionated granites in the Krušné hory/Erzgebirge Mts., Central Europe. Lithos 2012, 151, 105-121. [CrossRef]

36. Jarchovský, T. The nature and genesis of greisen stocks at Krásno, Slavkovský les-western Bohemia, Czech Republic. J. Czech Geol. Soc. 2006, 51, 201-216. [CrossRef]

37. René, M.; Škoda, R. Nb-Ta-Ti oxides fractionation in rare-metal granites: Krásno-Horní Slavkov ore district, Czech Republic. Miner. Petrol. 2011, 103, 37-48. [CrossRef]

38. Sejkora, J.; Ondruš, P.; Fikar, M.; Veselovský, F.; Mach, Z.; Gabašová, A. New data on mineralogy of the Vysoký Kámen deposits near Krásno, Slavkovský les area, Czech Republic. J. Czech Geol. Soc. 2006, 51, 43-55. [CrossRef]

39. René, M. Distribution and origin of clay minerals during hydrothermal alteration of ore deposits. In Clay Minerals in Nature-Their Characterization, Modification and Application; Valášková, M., Martynková, G.S., Eds.; IntechOpen: Rijeka, Croatia, 2013; pp. 81-100.

40. Machek, M.; Roxerová, Z.; Janoušek, V.; Staněk, M.; Petrovský, E.; René, M. Petrophysical and geochemical constraints on alteration processes in granites. Stud. Geophys. Geod. 2013, 57, 710-740. [CrossRef]

41. René, M.; Dolníček, Z.; Sejkora, J.; Škácha, P.; Šrein, V. Uraninite, coffinite and ningyoite from vein-type uranium deposits of the Bohemian Massif (Central European Variscan Belt). Minerals 2019, 9, 123. [CrossRef]

42. Whitney, D.L.; Evans, B.W. Abbreviations for names of rock-forming minerals. Am. Mineral. 2010, 95, 185-187. [CrossRef]

43. Jirásek, J.; Matýsek, D.; Škoda, R.; Skupien, P. Fosfáty a doprovodné minerály z živcového lomu Vysoký kámen u Krásna, Česká republika. Bull. Mineral. Petrol. Oddělení Nar. Muz. Praze 2016, 24, 80-94.

44. Hacifazlioglu, H.; Kursun, I.; Terzi, M. Beneficiation of low-grade feldspar ore using cyclojet flotation cell, conventional cell and magnetic separator. Physicochem. Probl. Min. Process. 2012, 48, 381-392.

45. Gulsoy, O.Y.; Can, N.M.; Bayraktar, I.; Ersayin, S.; Hizal, M.; Sahin, A.I. Two stage flotation of sodium feldspar-from laboratory to industrial application. Miner. Process. Extr. M. 2004, 113, 139-144. [CrossRef]

46. Burat, F.; Kokkilic, O.; Kangal, O.; Gurkan, V.; Celik, M.S. Quartz-feldspar separation for the glass and ceramics industries. Min. Metall. Explor. 2007, 24, 75-80. [CrossRef]

47. Polat, E.; Aksoy, A.A.; Bozkaya, A.; Tunç, S.; Küçükler, M.; Güler, T. Use of pinched sluice in albite concentration. Inżynieria Miner. 2017, 18, 33-38.

48. Menezes, R.R.; Ferreira, H.S.; Neves, G.A.; Lira, H.D.L.; Ferreira, H.C. Use of granite sawing wastes in the production of ceramic bricks and tiles. J. Eur. Ceram. Soc. 2005, 25, 1149-1158. [CrossRef]

49. Andreola, F.; Barbieri, L.; Lancellotti, I.; Leonelli, C.; Manfredini, T. Recycling of industrial wastes in ceramic manufacturing: State of art and glass case studies. Ceram. Int. 2016, 42, 13333-13338. [CrossRef]

50. Radulović, D.S.; Sekulić, Ž.; Mihajlović, S.; Jovanović, V. Waste material from the flotation Feldspar Bujanovac as raw material in the ceramic industry after removing the surplus of iron. J. Min. Metall. A 2005, 41, 67-78.

51. Breiter, K.; Hložková, M.; Korbelová, Z.; Galiová, M.V. Diversity of lithium mica compositions in mineralized granite-greisen system: Cínovec Li-Sn-W deposit, Erzgebirge. Ore Geol. Rev. 2019, 106, 12-27. [CrossRef]

52. Martin, G.; Schneider, A.; Voigt, W.; Bertau, M. Lithium extraction from the mineral zinnwaldite: Part II: Lithium carbonate recovery by direct carbonation of sintered zinnwaldite concentrate. Miner. Eng. 2017, 110, 75-81. [CrossRef]

53. Schneider, A.; Schmidt, H.; Meven, M.; Brendler, E.; Kirchner, J.; Martin, G.; Bertau, M.; Voigt, W. Lithium extraction from the mineral zinnwaldite: Part I: Effect of thermal treatment on properties and structure of zinnwaldite. Miner. Eng. 2017, 111, 55-67. [CrossRef]

54. Rentsch, L.; Martin, G.; Bertau, M.; Höck, M. Lithium extracting from zinnwaldite: Economical comparison of an adapted spodumene and a direct-carbonation process. Chem. Eng. Technol. 2018, 41, 975-982. [CrossRef]

55. Li, H.; Eksteen, J.; Kuang, G. Recovery of lithium from mineral resources: State-of-the-art and perspectives-A review. Hydrometallurgy 2019, 189, 105129. [CrossRef]

56. Choubey, P.K.; Kim, M.S.; Srivastava, R.R.; Lee, J.C.; Lee, J.Y. Advance review on the exploitation of the prominent energy-storage element: Lithium. Part I: From mineral and brine resources. Miner. Eng. 2016, 89, 119-137. [CrossRef]

57. Kaygili, O. Synthesis and characterization of paramagnetic Mn doped $\mathrm{Ca}_{2} \mathrm{P}_{2} \mathrm{O}_{7}$ ceramics by sol-gel method. J. Ceram. Proc. Res. 2015, 16, 54-58.

58. Ates, T.; Dorozhkin, S.V.; Kaygili, O.; Kom, M.; Ercan, I.; Bulut, N.; Firdolas, F.; Keser, S.; Canan Gursoy, N.; Ozercan, I.H.; et al. The effects of Mn and/or Ni dopants on the in vitro/in vivo performance, structural and magnetic properties of $\beta$-tricalcium phosphate bioceramics. Ceram. Int. 2019, 45, 22752-22758. [CrossRef]

59. Zilm, M.E.; Yu, L.; Hines, W.A.; Wei, M. Magnetic properties and cytocompatibility of transition-metal-incorporated hydroxyapatite. Mat. Sci. Eng. C 2018, 87, 112-119. [CrossRef] [PubMed]

60. Pauliš, P.; Ludvík, J.; Pour, O.; Malíková, R. Hollandit z Vysokého Kamene u Krásna. Minerál 2014, 22, 530-532.

61. Tkaczyk, A.H.; Bartl, A.; Amato, A.; Lapkovskis, V.; Petranikova, M. Sustainability evaluation of essential critical raw materials: Cobalt, niobium, tungsten and rare earth elements. J. Phys. D Appl. Phys. 2018, 51, 203001. [CrossRef]

62. Blengini, G.A.; Nuss, P.; Dewulf, J.; Nita, V.; Peirò, L.T.; Vidal-Legaz, B.; Latunussa, C.; Mancini, L.; Blagoeva, D.; Pennington, D.; et al. EU methodology for critical raw materials assessment: Policy needs and proposed solutions for incremental improvements. Resour. Policy 2017, 53, 12-19. [CrossRef] 
63. Dehaine, Q.; Filippov, L.O. Rare earth ( $\mathrm{La}, \mathrm{Ce}, \mathrm{Nd})$ and rare metals $(\mathrm{Sn}, \mathrm{Nb}, \mathrm{W})$ as by-product of kaolin production, Cornwall: Part 1: Selection and characterisation of the valuable stream. Miner. Eng. 2015, 76, 141-153. [CrossRef]

64. Dehaine, Q.; Filippov, L.O.; Joussemet, R. Rare earths (La, Ce, Nd) and rare metals (Sn, Nb, W) as by-products of kaolin production-Part 2: Gravity processing of micaceous residues. Miner. Eng. 2017, 100, 200-210. [CrossRef]

65. Filippov, L.O.; Dehaine, Q.; Filippova, I.V. Rare earths (La, Ce, Nd) and rare metals (Sn, Nb, W) as by-products of kaolin production-Part 3: Processing of fines using gravity and flotation. Miner. Eng. 2016, 95, 96-106. [CrossRef] 